\title{
ХИБРИДНИ СУШТЕСТВА И ЗЛИ ДЕМОНИ: ВОВЕД ВО МЕСОПОТАМСКИТЕ ВЕРУВАҢА ВО „ИНКАРНИРАНОТО“ ЗЛО
}

\begin{abstract}
$A \bar{u} c \bar{u} p a \kappa \bar{u}$. - Целта на овој текст е да понуди прелиминарен терминолошки и концептуален вовед во, односно преглед на, основните елементи на месопотамските верувања во хибридните суштества и различните претставници на „инкарнираното“ зло, односно демоните кои се идентификувани, опишувани и изгонувани преку егзорцизам од Инканйациите йротиив зли яемони (Udug-hul или Utukku

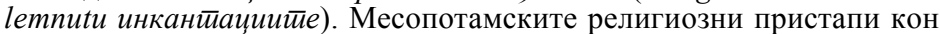
нечовечките суштества се занемарена тема во локалното интелектулано милје, и затоа целта на текстот е само да воведе иницијални концепти од избраните книжевни и медицинско-магиски извори, но не и да навлезе во компаративна анализа на разновидните хибридни и/или зли суштества, ниту во интердисциплинарно истражување на формите, содржините и значењата на достапните извори во кои се споменуваат хибридите, чудовиштата и демоните.
\end{abstract}

Трите групи (и типови) на суштества на кои им се обрнува внимание во текстот се таканаречените „Чудовишта“" од раскажувањата за космогонијата; разновидните хибриди од Визијайа на Пооземје$\bar{u} о$ на асирскиот̄ йрини; и злите демонски дејствители идентификувани како закани, кои мора да бидат набркани преку строги егзорцистички ритуали од Инканйащиитее. Така, првин се разгледани Чудовиштата, групата на Четирите ветра, и космогониски релевантните Мудреци, натприродни хибриди, кои иако имаат доза на амбивалентност, никако не се демонски дејствители. Потоа, накратко е

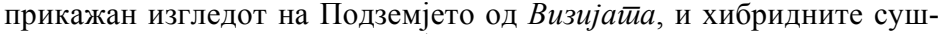
тества кои се мрачни и злокобни служители на Нергал, но не и демонски закани над земјата. Најголемо внимание е обрнато на различните демони од Инканйациитее, при што може да се резимира дека, иако се знае за ужасот кој демоните го предизвикуваат (како вектори за болестите, и како зли причинители на енвиронментални, земјоделски, социјални и интерперсонални проблеми и страдања), како и за некои нивни атрибути (на дел од кои им се пристапува апофатички), поради нивната лиминална и скриена природа, тешко може да се утврди кои се нивните суштински карактеристики, та затоа прегледот на демоните доминантно се однесува на нивните штетни и злокобни дејства, и нужноста од егзорцистичка исцелителска интервенција. 


\section{Основни определби на хибридите и чудовиштата}

Целта на овој текст е да даде прелиминарен вовед во, односно преглед на, концептот на „инкарнираното“1 зло преку верувањето во демоните во месопотамската религиозна традиција, подрачје занемарувано на овие простори. Во таквата намера од почетокот се јавуваат неколку проблеми. Религиозната и книжевната култура на Месопотамија се простираат низ илјадалетија, и затоа секое споменување на партикуларни инстанции без соодветен компаративен пристап страда од претерани генерализации или силен редукционизам. Покрај ова, концептот на демонското е врзан со други концепти, како хибридното и чудовишното, кои со текот на времето имаат примено инакви значења, што може да води кон анахронистички толкувања.

Потоа, иако може да се определи што демоните прават (како и зошто дејствуваат), поради нивната лиминална и ретко дефинирана природа, не може токму да се каже какви се. Иако се знае за ужасот кој го предизвикуваат и за некои нивни атрибути, тешко може да се утврди кои се нивните суштински карактеристики, та затоа прегледот на демоните доминантно се однесува на нивните (штетни и злокобни) дејства. Поради тоа, овој вовед може да понуди само основни терминолошки и концептуални определби, без да навлезе во подлабоки интерпретативни потфати или интердисциплинарно истражување на феноменот на верувањето во злото, разновидните месопотамски сфаќања на инкарнираното зло, и импликациите на таквите верувања врз другите сфери од религиозниот (и севкупниот) живот.

Во текстот првин се дадени основни определби на концептот на хибридноста и чудовишноста, како и на лиминалноста на демонското, за да се постави проблемот во рамките на религиската (односно теолошката) сфера. Низ одбрани примери од постоечките извори се лоцираат концепции за хибридни, чудовишни, односно демонски суштества. Направен е краток преглед на хибридните суштества од Визијайа на йоэземјетио. Најопсежно внимание е посве-

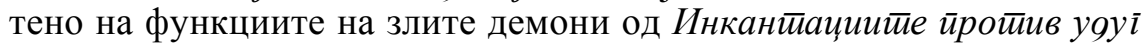
$x y л$ (корпусот на канонски инкантации познат како $Y_{9 y \bar{i}-x y л / U d u g-}$ $h u l$, или Utukkū Lemnūtu), т. е. на начините на кои демоните дејствуваат, и потребата егзорцистички врз нив да се интервенира.

Хибридните суштества од месопотамските верувања, во кои постои изобилство на концептуализирани чудовишта, се главно демонски. Често се работи за концепции на мешани суштества или

${ }^{1}$ Во овој контекст наводниците посочуваат дека не во сите инстанции на верувања во некакво интенционално зло суштество се работи за негово телесно, физичко присуство. „Инкарнирано“ зло се применува на сите суштества кои имаат зла и штетна природа и соодветни (демонски или чудовишни) карактеристики. 
меѓусуштества (за кои се соодветни германските кованици Misch/en/wesen и Zwischenwesen), кои имаат хибридна физичка форма, и кои посредуваат меѓу повисоките и пониските онтолошки сфери. Чудовиштата и демоните живеат во местата надвор од уредениот свет, како пустините, океаните, перифериите на уредената сфера, подземјето, смета Смит, одредувајќи „локативна“ категорија на чудовиштата. ${ }^{2}$ Ако чудовиштата се концептуализираат како хибриди со композитни животински тела, а демоните како хибриди со човечки карактеристики, но со јасна малициозна насоченост, може да се тврди дека чудовиштата им припаѓаат на местата повеќе од демоните, според ставот на Смит. Демоните „бегаат од местото“; бивајќи зли и опасни, тие го претставуваат хаосот, она што е неуредено, неодредено, далечно, непријатно непознато, заканувачко, бунтовничко.

Сугестиите на Смит добро се применуваат на истражувањето на демоните општо земено, смета Џонстон. Таа има додатни опсервации за тоа како негативните карактеристики на демоните и духовите ги отсликуваат и засилуваат структурите преку кои културата ги организира нејзините физички и морални светови. ${ }^{3}$ Мошне често „депласирањето“ на демонското се изразува како лиминалност. Демонот или демонското не е само надвор од една дадена категорија, туку се наоѓa точно меѓу две категории кои се инаку меѓусебно исклучувачки. Менувањето на формата, вообичаен демонски талент, е повеќе дијахрониски отколку синхрониски вид на хибридност: демонот не нужно ги покажува симултано карактеристиките на една или повеќ категории (како што, на пример, врколакот е човек и волк). Во спротивставувањето на утврдените категории, асоцијацијата меѓу лиминалноста и демонското всушност помага да се одржуваат тие категории, сугерирајќи дека сѐ што спаѓа меѓу нив е опасно и мора да биде одбегнувано. Демоните кои по дефиниција уживаат во повредувањето или оштетувањето на луѓето (значи, ги извртуваат правилата на цивилизирано човеково однесување), често се замислуваат во физички форми кои се лиминални, затоа што се хибридни. ${ }^{4}$

Во месопотамските јазици нема термин што совршено би кореспондирал со „чудовиште“. Оние суштества што сега се сметаат за чудовишта биле именувани според нивните териоморфни карактеристики (како „животни“) или според нивните функции како извршители на божествената волја (како „констабли“, gallû или ūmū, „дневни демони“). Чудовиштата се текстуално дефинирани како

${ }^{2}$ J. Z. Smith, "Towards Interpreting Demonic Powers in Hellenistic and Roman Antiquity”, $A N R W$ II, 16. 1(1978), 429.

${ }^{3}$ S. I. Johnston, Restless Dead - Encounters between the Living and the Dead in Ancient Greece (Berkeley-Los Angeles-London: University of California Press, 1999), 171172.

${ }^{4}$ Johnston, Restless Dead, 173. 
група преку нивното појавување во ритуалите против натрапничкото зло, во описите на уметничките дела во храмовите и палатите, и особено во Енума елиш, каде ја сочинуваат војската на примордијалното море, Тиамат. ${ }^{5}$ Пред Енума елиш, колку што може да се забележи, има само ретки назнаки за потеклото и природата на Чудовиштата. ${ }^{6}$ Некои од нив биле бунтовни, некои (како Лахму) имале улога во космогонијата. Хибридноста на Чудовиштата од Енума елиш се должи на концепцијата за нивното потекло во примордијалното, предвременско, „пред-нормално“ постоење, во ембрионскиот (неиздиференциран) космос. Секако дека Морето, Тиамат, не е антропоморфно, што е типично за основните принципи во космогониските митови.

Многу малку се знае за изгледот на божествата од примордијалниот космос. Сепак, хибридноста како нужно поврзана со примордијалниот хаос и диференцирањето на космосот е јасно покажана во текстот на Истиоријайа на Бабилонија од Берос. Во текстот се раскажува како според Тој (Оан/Уана или У-Ан, првиот рибомудрец), постоело време кога сѐ било темнина и вода, од која настанале чудни суштества со чудни форми. Така, луѓето биле родени со две крила, или со четири крила и две лица. Тие имале по едно тело и две глави, и биле и машки и женски, со машки и женски полови органи. Исто така, биле родени и други луѓе, со измешани делови од животни, и со двојни или тројни парови екстремитети, и секакви суштества во форма на разни видови на зверки, риби, змии и уште поизвонредно различно формирани суштества кои се разликувале по изгледот едни од други.

Разликата меѓу Чудовиштата и месопотамските демони е во тоа што Чудовиштата, и покрај врската со инцијалната агресија, никогаш не биле сметани за донесувачи на страдање или на болест. Примордијалните Чудовишта на Морето се однесувале како платеници. Поразени од боговите на редот, едноставно се префрлиле во нивна служба да вршат апотропејска функција, станувајќи заштитници од демоните што се заканувале на земјата, на кралот, на луѓето. Овие апотропејски хибриди, или чудовишта, низ архитектурата се забележуваат на портите, на sидовите, на sидините, под подовите на палатите и домовите. Покрај ова, претставите на Чудови-

${ }^{5}$ F. A. M. Wiggermann, "The Mesopotamian Pandemonium - A Provisional Census”, SMSR 77 (2/2011), 302; F. A. M. Wiggermann, Mesopotamian Protective Spirits: The Ritual Texts (Groningen: Styx\&PP Publications, 1992), 222-264.

${ }^{6}$ Во овој контекст е соодветна употребата на големата почетна буква - се работи за специфична група со значајно место во космологијата и митологијата.

${ }^{7}$ Берос го завршува описот споменувајќ́ дека сликите на овие суштества се поставени во храмот на Бел (Мардук), што соодветствува со клинописната верзија на космогонискиот мит, каде Мардук поставува статуа на поразените чудовишни војници на Тиамат на портите на Апсу, за да биде потсетник, и никогаш да не се заборави, S. Mayer Burstein, The Babyloniaca of Berossus, Sources from the Ancient Near East 1.5 (Malibu: Undena Publications, 1978), 14-15. 
шата извршувале апотропејска функција и на амајлиите што се носеле на телото, или на цилиндричните печати низ различните периоди. Чудовиштата како членови на компактна група на духови-помагатели треба да се разликуваат од хибридите, меѓутоа. Хибридите се дел од мошне поголема и некохерентна група која се менувала низ времето, која ги исклучува големите богови, а вклучува некои од помалите божества, Мудреците, повеќето од ,службениците“ од Подземјето, и во подоцните периоди, злите демони.

Група која може да се асоцира („формално и функционално“, како што определува Вигерман) $)^{8}$ со Чудовиштата, е таа на Четирите ветра. ${ }^{9}$ Се работи за натприродни хибриди, кои иако понекогаш носат круни со рогови, не се сметаат за наполни божества и не фигурираат на списоците на богови. Четирите ветра се разуздани, но не се дејствители на болест и зараза, туку, како Чудовиштата, може да се однесуваат како заштитни духови во служба на боговите. Демонот на ветрот, Пазузу, има амбивалентнта функција: тој е истовремено зол демон и заштитник.

Ветриштата може да се сметаат како натприродни патници, дома и низ светот. Преку разни печати се потврдува дека природната средина на ветровите е токму природата: тие се опкружени со див свет, или се скротители на животни (особено Јужниот ветер). Во оваа смисла, се верувало дека повикани во соодветни ритуали, може да ги заштитат полињата од штетници. ${ }^{10}$ Во врска со ветровите се забележува одреден степен на амбивалентност. Јужниот ветер е ветрето на Еа, чие дување е благонаклоно, ${ }^{11}$ и во инкантациите таа (јужниот ветер е со женска природа) се повикува да се здружи со браќата против убиствените непријатели. ${ }^{12}$ Во нејзиниот зол аспект, Јужниот ветер е ист како алу-демонот, кој ја покрива земјата.

Општо говорејќи, ветрињата, ветровите и бурите претставуваат добри, зли, или неутрални намери. Така, постојат следниве концепти. Алу е демонизиран атмосферски феномен, можеби из-

\footnotetext{
${ }^{8}$ Wiggermann, "The Mesopotamian Pandemonium - A Provisional Census", 305.

${ }^{9}$ Почетна точка за дискусијата за ветровите е цилиндричен печат, веројатно од Сипат, во доцниот деветнаесетти век пр. н. е. На печатот се претставени четири џиновски крилести суштества, околу помал бог на бурата, или лаво-грифон кој плука вода. Поврзувањето на четирите суштества со богот на бурата не е случјано, затоа што се покажува и во серија на современи и подоцнежни печати, смета Вигерман, F. A. M. Wiggermann, "The Four Winds and the Origins of Pazuzu", J. Hazebos, A. Zgoll, C. Wilcke (Eds.), Das geistige Erfassen der Welt im Alten Orient Beiträge zu Sprache, Religion, Kultur und Gesellschaft (Wiesbaden: Harrassowitz Verlag, 2007), 127.

${ }^{10}$ A. R. George, "The Dogs of Ninkilim: Magic against Field Pests in Mesopotamia", CRRAI 41, BBVO 18 (1999), 299.

${ }^{11}$ R. Borger, Die Inschriften Asarhaddons, Königs von Assyrien (Graz: BAfO 9, 1956), 45 , ii, 3.

${ }^{12}$ G. Meier, "Keilschrifttexte nach Kopien von T. G. Pinches. Aus dem Nachlass veröffentlicht und bearbeitet. 10. Ritual für das Reisen über Land", AfO 12 (1937-1939), 142, ii, 24.
} 
ворно идентичен со Бикот на небото; гулулу е демон на ветрот; идипту е налет на ветер, демон кој се наоѓ на портата на Подземјето. Потоа, имхулу е зол ветер; шару е дух-ветер, се однесува и на боговите и на мртвите, а се смета и за причина за болест. На Пазузу, на пример, се реферира како на „шару“. Шеху е ветер, здив, пројава, еманација, и некој може да биде опседнат од него. Уму е дневен демон, насилен демон на лошите вести, кој се пројавува во бурното време. Закику е фантом, опседнувачки дух, дух од замината душа, како и бог на соништата. Некои закику се воздушести, немоќни и безопасни, но може да предизвикуваат болести. Покрај ова, умеат да пренесувааат пораки од боговите во соништата (така, Ветрето, богот на сонот, е ,син на Шамаш““).

Во нивните потфати против страдањето и болестите, примордијалните Чудовишта и Ветровите биле поддржувани од Седумте мудреци. Од доцното бронзено доба натаму, кога митологијата била реструктурирана, се јавува визуелен и текстуален материјал за овие суштества. Айкалу (акад.) или Aбїал (сум.) се термини најдени во клинописните натписи, што општо земено значат ,мудар“",мудри“, односно „мудреци“. ${ }^{13}$ Во неколку контексти Апкалу ce седумте полубожества, понекогаш опишувани како делумно луѓе, делумно риби, асоцирани со човечката мудрост и познание. Низ научната книжевност за овие суштества се зборува како за „Седумте мудреци“. Понекогаш мудреците се асоцираат со специфичен примордијален владетел. После дилувијалните случувања се споменуваат други мудреци и кралеви, со тоа што мудреците се сметаат за луѓе, и во некои извори се разликуваат така што се нарекуваат „Уману“, не „Апкалу“. Како знак на мудрост и знаење, термините „Апкалу“ (и „Абгал“) се употребуваат и како епитети за боговите и кралевите, како Еа и Мардук (мудри меѓу боговите), или Енлил, Нинурта и Адад, и за мудреците како Адапа. ${ }^{14}$ Терминот „Апкалу“ е употребуван и при реферирањето на фигурите од апотропејските ритуали, кои вклучуваат човекорибји хибриди кои ги претставуваат Седуммината, но и птицоглави и други мешани суштества. Првиот од Седумте, според Истиоријайа на Бабилонија, на луѓето им пренесол знаење, и ги им го кажал космогонискиот мит, Енума елиш. Ова е од огромно онтолошко значење, затоа што знаењето на космогонијата го претпоставува знаењето на сѐ друго. Раскажувањето на космогонијата овозможува што било да почне, да биде создадено, научено.

13 Одделувањето во мета-јазик низ текстот понекогаш е со помош на наводници, а понекогаш со употребата на курзив. За ова нема поважен разлог, освен потребата текстот да не биде преоптоварен со премногу наводници, и да се даде извесна разиграност на четивото.

${ }^{14}$ M. Civil, I. J. Gelb, B. Landsberger, A. L. Oppenheim, E. Reiner (eds.), The Assyrian Dictionary, part 2 (Chicago: Oriental Institute of the University of Chicago, 1968), 172-173. 
Првиот од митолошките мудреци риболуѓе е Оан (сум.) или Уана/У-Ан (акад.). ${ }^{15}$ Се раскажува дека во првата година се појавило, од дел од еритрејското море, животно обдарено со разум, наречено Оан. Целото тело на животното било како она на риба; и под рибјата глава имало уште една глава, и стапала под тоа, слични на тие на човек, поврзани под рибјата опашка. Неговиот глас, и јазикот, биле артикулирани и човечки. Претстава на него е зачувана до ден денс (од раскажувањето според Аполодор). Важно (и корисно) е дека суштеството им дава на луѓето увид во писменоста и науката, и секаков вид на уметност. Според приказната, тоа ги научило луѓето како да конструираат живеалишта, да основаат храмови, да составуваат закони, и им ги објаснило принципите на геометриското знаење, како да ги разликуваат семињата од земјата, и како да собираат плодови. Накратко, ги поучило за сѐ што може да ги омекне манирите и да го очовечи човештвото. Толку биле универзални и соодветни неговите поуки, што ништо не требало да се додаде на тој материјал за да се подобри. ${ }^{16}$

Покрај ова, се смета дека Оан пишувал за создавањето на човештвото, за различните видови на живот на луѓето, за нивните општествени и правни смерници. Во овој зачуван текст потоа следи скратена верзија на Енума елиш, што Берос му ја припишува на Оан (идентичен со примордијалниот Мудрец Уана/Уана-Адапа), ${ }^{17}$

${ }^{15}$ Се верува дека Мудреците се: Уана (Оан), кој ги завршил плановите за небото и земјата; Уанедуга, кој бил обдарен со сеопфатна интелигенција; Енмедуга, кому му била проречена добра судбина; Енмегалама, кој бил роден во куќа; Енмебулуга, кој пораснал на пасиште; Ан-Енлилда, создавачот на градот Ериду; и Утуабзу, кој се искачил на небото и кој на неколку клинописни натписи се појавува како „адапа“. За списокот на овие личности види кај A. Lenzi, “The Uruk List of Kings and Sagen and Late Mesopotamian Scholarship”, JANER 8.2 (2008), 137-169.

Веројатно не се работи за споменатиот Адапа, рибарот од митот за Адапа, синот на Еа, туку можно е терминот „адапа“ да се употребувал како апелатив за „мудар“, R. Borger, "The Incantation Series Bīt Mēseri and Enoch's Ascension to Heaven", R. S. Hess, T. D. Tsumura (Eds.), "I studied inscriptions from before the flood", Ancient Near Eastern, literary, and linguistic approaches to Genesis 1-11 (Winona Lake: Eisebrauns, 1994), 228-229. Кванвиг смета дека треба да се земе предвид дека Адапа е еден од Апкалу, или дека е име за некој од Апкалу. За паралели меѓу приказните и определувањето на сличностите меѓу Адапа и првиот и последниот Апкалу, кај $\mathrm{H}$. Kvanvig, Primeval History: Babylonian, Biblical, and Enochic: An Intertextual Reading (Leiden: Brill, 2011), 117-129.

${ }^{16}$ I. P. Cory, The Ancient Fragments; containing what remains of the writings of Sanchoniatho, Berossus, Abygenus, Megasthenes, and Manetho (London: William Pickering, 1828), 24-38.

${ }^{17}$ Интересно е што долгата форма на името може да се чита како првиот ред од Енума елиш напишан логографски. Според ова, припишувањето на космогонискиот текст на предокот (односно воведувачот) на писарската вештина, на писменоста и науката, веројатно постоело долго пред Берос. Вигерман потсетува дека првиот ред гласи „Кога (y/u) горе (анна/anna) небесата (aн/an) не беа (an/ан) сѐ уште именувани (пада/pada)“ - содржењето на името е очигледно. Ова значи дека космогонијата ста- 
според верзијата од Александар Полихистор, зачувано кај Евзебиј и Синкел. ${ }^{18}$

Како Чудовиштата и Четирите ветра, и Мудреците се натприродни хибриди, но не се богови, иако понекогаш се претставувани со роговите на божественоста. Како Чудовиштата, Мудреците се спротивставуваат на неволјите и на болестите, но тоа не го прават со груба сила, туку со прочистувачките ритуали кои ги донеле со себе од длабочините на примордијалниот поток. Со тоа што Мудреците се донесувачи на знаењето и на учењето, се сметале за заштитници на научниците, и на егзорцистите, зналци кои ги прочистувале жртвите на демоните, ритуално набркувајќи ги. Може да се резимира дека примордијалните демони се соперници на Мудреците, а Чудовиштата им се сојузници.

\section{Хибридните суштества од Визијайа на Поэземјеш̄о}

Подоцнежната демонологија е помалку прецизна во разликувањето меѓу примордијалните непретставливи сѐ-уште-не-суштества од една страна, и примордијалните духови кои помагаат (Чудовиштата и Мудреците) како хибриди. ${ }^{19}$ Во следниот дел ќе бидат накратко опишани хибридните суштества што може да се сретнат во Подземјето. Тие се вклопуваат во општата злокобна атмосфера, но не се демони. Не дејствуваат како демони, ниту нивната улога во Подземјето е онаа што стандардно им се припишува на демоните на земјата: да носат неволји, болештини, непогоди, односно општа и индивидуална мизерија.

Асирското Подземје било опишувано како мрачен „пекол“ чии жители се како птици, лишени од светлина, и имаат земја и глина како храна. Тоа е земјата од која нема враќање, куќата која никој кој влегол не ја напушта, до која се стигнува преку патека која не дозволува враќање. Покрај како мрачен пекол, меѓутоа, асирското Подземје треба да се гледа и како место за иницијација. Херојот, или духовниот патник, него може да го посети додека е сѐ уште жив, и како резултат се здобива со нови знаења и го менува животот. ${ }^{20}$

нува извештај од сведок, пренесен кон сегашноста од Мудрецот кој го напишал и од неговите наследници (Wiggermann, "Mesopotamian pandemonium”, 306).

${ }^{18}$ Cory, The Ancient Fragments; containing what remains of the writings of Sanchoniatho, Berossus, Abygenus, Megasthenes, and Manetho, 36-38. За претпоставените поклопувања меѓу Берос и кралевите и апкалу во Сйисокот̄ на кралеви на Урук, види Mayer Burstein, The Babyloniaca of Berossus, 18-19.

${ }^{19}$ Wiggermann, "The Mesopotamian Pandemonium - A Provisional Census", 309.

${ }^{20}$ W. Horowitz, Mesopotamian Cosmic Geography (Winona Lake, Indiana: Eisen, 1998), 268 ff. За патувањето кон Подземјето, како одење/лизнување, за начините на премин кон, и за излегувањето од Подземејто, кај D. Katz, The Image of the Netherworld in Sumerian Sources (Bethseda, MD: CDL Press, 2003), 32-42. 
Општо земено, подоцните текстови ги опишуваат сите демони и слуги од Подземјето како хибриди, што значи дека формално не се разликуваат од групата на чудовишни помагачки духови. Во Визијат̄а на Пооземјет̄o, ${ }^{21}$ на пример, опишан е бог или дух (илу), ,зол утуку“ (утуку односно удуг, зол демон) како хибрид со лавовска глава и рацете и нозете како анзу-птица. Овој неоасирски текст од седмиот век пр. н. е., може да се смета како прво патување во пеколот низ визија, антиципирајќи ги апокалиптичните патувања отаде, како тие од Книіите на Енох, Ойкровениейо йо Јован, или најпознатото такво патување, Пеколой од Божесиивенайа комеquja. $^{22}$

Во две илјади години клинописна книжевност нема други примери од жанрот - најслично дело е Книіат̄а на Набљуяувачитие од Книіите на Енох. Очигледни се митските и епските корени во симнувањата во Подземјето од месопотамската традиција (Инана и Гилгамеш), но постојат и разлики од сумерските и акадските претходници. ${ }^{23}$ Може да се смета дека интегрирајќи го форматот (и на некој начин содржината) на таканаречениот Göttertypentext (скратено како GTT) ${ }^{24}$ во текстот на Визијайа на Пояземјейо, авторот можеби вовел ,филозофски“ дискурс во раскажувањето. ${ }^{25}$

Протагонистот е човечко суштество, не бог или полубог од митското минато, кој патува кон Подземјето не физички, туку во сон, односно низ ноќна визија. Така, искусува откровение од божеството на престолот, пред кое паѓа од страв. Откровението се однесува на предокот на протагонистот, голем земски крал кој сега лежи закопан во Подземјето. Увидот во божествената правда завршува со порака од божеството, кое го прекорува протагонистот водејќи го кон промена во личноста и однесувањето кога ќе се вра-

${ }^{21}$ Иако во македонскиот јазик вообичаената формулација е „визија за“, во овој контекст е употребена формулацијата „визија на“, затоа што акцентот е врз искусувањето преку учество, преку впечаток на дејствување, а не само на набљудување. Користено е изданието "The Underworld Vision of an Assyrian Prince", Court Poetry and Literary Miscellanea, A. Livingstone (Ed.), (Helsinki: Helsinki University Press, 1989), 68-76, од таблицата VAT 10057, според верзијата ZA 431.

22 За влијанијата, види, на пример, кај Колинс, кој смета дека „формално, визијата е од големо значење за заднината на раните еврејски апокалипси, но е порелевантна за патувањата во светот отаде на Енох, отколку за симболичката визија на Даниел“, J. J. Collins, Seers, Sibyls and Sages in Hellenistic-Roman Judaism (Leiden: Brill, 1997), 147-148. Кванвиг смета дека се работи за позадина за Даниел 7 - H. S. Kvanvig, “An Akkadian vision as background for Dan 7?", Studia Theologica - Nordic Journal of Theology 35:1 (1981): 85-89.

${ }^{23}$ S. L. Sanders, "The First Tour of Hell: from Neo-Assyrian Propaganda to Early Jewish Revelation", Journal of Ancient Near Eastern Religions 9 (2009): 151-152.

${ }^{24}$ Sanders, "The First Tour of Hell: from Neo-Assyrian Propaganda to Early Jewish Revelation", 156-158.

${ }^{25}$ J. Bach, "A Transtextual View on the 'Underworld Vision of an Assyrian Prince"”, S. V. Panayotov, L. VacÍn, (Eds.), Mesopotamian Medicine and Magic - Studies in Honor of Markham J. Geller (Leiden-Boston: Brill, 2018), 70. 
ти на земскиот живот. Текстот е раскажуван во трето лице, но визијата ја крши ваквата враменост, префрлајќи се во исповед во прво лице, и во раскажувачки пресврт, самата приказна станува искупување на раскажувачот за гревот кој бива осуден во визијата. Како што формулира Сандерс, раскажувањето е оживеано од такви чудни стилистички карактеристики, како „преобилен, педантериски научен список на богови и демони кој завршува со признанието на раскажувачот дека не ги знае имињата на последните двајца (r.8), и со епски компарации кои кулминираат со сликата на свиња во сексуален однос (r.30-31)“. ${ }^{26}$

Текстот ја опишува непријатната ситуација во која се наоѓa Кума(ј) (или Кумаја), принц кој минува низ личносна криза. После оштетен дел од текстот, Кума е претставен како се консултира со претскажувачи за помош, ${ }^{27}$ и трупа скапоцености. ${ }^{28}$ Опкружен со изобилство, тој е сепак во паника, не се одмара ноќе, ниту престанува да липа. ${ }^{29}$ После втор наплив на липање, решава да оди во Подземјето; и намерно се обидува да предизвика визија или токму патување. Можно е ваквата горделивост во желбата да ја премине границата меѓу светот на мртвите и на живите да е разлогот за ужаснувачката визија што ја искусува, веќе од претходно бивајќк емоционално лабилен. ${ }^{30}$

Молејќи се за помош од Ерешкигал, кралицата на Подземјето, Кума некако ја навредува, иако нејасно како (тој го разгневил срцето на бога, додека постојано изговарал благослови). ${ }^{31}$ Таа му се појавува во сон, само за да му каже дека нема намера ништо да му

${ }^{26}$ Sanders, "The First Tour of Hell: from Neo-Assyrian Propaganda to Early Jewish Revelation", 156.

27 "The Underworld Vision of an Assyrian Prince", I.2.

${ }^{28}$ Op. cit., 8.

${ }^{29}$ Op. cit., 19.

${ }^{30}$ Адапа, получовечкиот мудрец кој успешно влегува во рајот, исто така се појавува и во патување во Подземјето со страшни последици. Текстот за Адапа е претерано уништен за да има конзистентна наративна смисла, но се чини дека наликува на Визијайа на йоэземјетио во описот на обидот, поттикнат од тага, да sирне „во живо“ во животот после смртта, како и во вознемирувачката природа на тоа што се дознава таму. Емоционалната нестабилност се чини како првиот чекор кон лиминалниот премин од овој тип. Според раскажувањето за Адапа, тој веројатно липал на Мардук, а резултатот е во тоа што боговите реагираат некако на тажачката, но се чини дека не помагаат. Во ова се вмешува кралот, и така заедно со Адапа се симнуваат во земјата и влегуваат во гроб. Можно е да прават извесна форма на некромантија, затоа што се споменува древен труп од најдалечните времиња. Се симнуваат низ длабочините и ја уништуваат вратата на гробницата, после што има некакво трауматично искуство, кое не е зачувано. Кога текстот повторно станува читлив, исплашени, бараат од ковач да ја запечати гробницата, и кога Адапа повторно го сретнува ковачот вознемирено прашува дали вратата кон гробот е сигурно затворена користен е текстот во B. Foster, Before the Muses (Columbia, MD: CDL Press, 2005), 531-532.

31 "The Underworld Vision of an Assyrian Prince", 29. 
каже („Нема да ти одговорам“). ${ }^{32}$ Принцот се буди, проколнувајќи го сонот и плачејќи, и повторно ѝ се помолува. Потоа искусува наполно оформена визија на Подземјето, која не е токму сон, или секако не е обичен сон. ${ }^{33}$

Темелниот список на присутните ужаснувачки суштества го следи мошне познатиот формат на текстови како $G T T$, начин на опишување на сликите на боговите и на демоните што оди од главата кон рацете и нозете, кон предметите што тие ги носат или ги газат. Кума е заробеник (...), и го гледа застрашувачкиот сјај (во Подземјето). ${ }^{34}$ Кума раскажува: „го видов Намтар, везирот на подземниот свет, кој прави претскажувања со помош на утроби“. Пред Намтар стоел човек, додека му ја држел косата во неговата лева рака, и мавтајќи со бодеж во десната рака. ${ }^{35}$ Намтарту, неговата жена, имаше глава на херувим, ${ }^{36}$ раскажува Кума, со човечки раце и нозе. Смртта ја имаше главата на змеј, неговите (машкиот род е поради машката природа на Смртта) раце беа човечки. ${ }^{37}$

Злобниот дух имаше човечка глава и раце, раскажува Кума, беше крунисан со дијадема, и имаше нозе на орел. Со левата нога газеше врз крокодил. Алухапу имаше лавовска глава, а неговите четири раце и нозе беа како тие на човечките суштества. ${ }^{38}$ Одржувачот на Злото, продолжува Кума, е со глава на птица, со раширени крила, и лета наваму-натаму. Бродарот на Подземјето, пак, имал глава како анзу, а неговите четири раце и нозе $(. . .)^{39}$ (поради тоа што недостасува текстот, не знаеме какви се, но по примерот на претходните суштества, можно е да се човечки). Духот (,етему“), имаше глава на вол, продолжува раскажувањето, а неговите четири раце и нозе се како тие на човечките суштества, се објаснува во текстот. Утуку лему, Злобниот дух (се работи за суштество различно од претходно споменатиот Зол дух), е со лавовска глава, а неговите раце и нозе се тие на Анзу. Шулак, во визијата е лав (инаку

${ }^{32}$ Op. cit., 36.

33 За разликата меѓу сон и визија и карактеристиките на визијата, види кај I. Winter, "The Eyes Have It: Votive Statuary, Gilgamesh's Axe, and Cathected Viewing in the Ancient Near East", R. S. Nelson (Ed.), Visuality Before and Beyond the Renaissance. (Cambridge: Cambridge University Press, 2000), 22-44, особено 33ff.

34 "The Underworld Vision of an Assyrian Prince", r.1.

${ }^{35}$ Op. cit., r.2.

36 Употребата на „херувим“ (неточно во множина), како концепт од библиската христијанска традиција е несоодветна во овој случај, но е направена за да се разлачи од неколку пати споменатите мешани суштества (хибриди), односно да се истакне како посебен вид на Mischenwesen. Замислата за херувимот како крилесто дебелко момче, пак, треба да се разликува од изворната концепција за херувимите како супериорни суштества од небеската хиерархија, со ангелски функции и сложена онтологија.

37 "The Underworld Vision of an Assyrian Prince", r.3.

${ }^{38}$ Op. cit., r.4.

${ }^{39}$ Op. cit., r.5. 
познат како демон кој се прикрадува и демне во тоалетите), застанат на своите задни нозе (значи може да се замисли со става на човек). ${ }^{40}$ Заклетвата (се работи за заклетва персонифицирана во машко хибридно суштество), има козја глава, неговите раце и нозе се човечки. Неду, носачот на Подземјето, има глава на лав, човечки раце, а нозе на птица. Мима лемну, Наполното Зло (односно, „Што било Зло“), пак, има две глави, од кои едната е на лав (не е зачувано каква е другата). ${ }^{41}$ Следното суштество, „Мух(а?)ра“, има три стапала, двете предни се како како на птица, а задното како нога на бик. Тој имал застрашувачки и осветлувачки сјај. Кума додава дека има и два бога чии имиња не ги знае, од кој едниот имал глава, раце и нозе на Анзил/Анзу (остатокот не е зачуван). ${ }^{42}$,Другиот“ (од боговите) има глава на човек, крунисан со дијадема, и во десната рака држи боздоган. Севкупно биле присутни петнаесет бога, кои Кума ги видел и ги поздравил со молитва. ${ }^{43}$ Покрај тоа, во Подземјето е присутен човек, катран црн во телото и со лице како Анзу, облечен во црвен оклоп. Во неговата лева рака тој носи лак, а во десната рака носи кама, додека со левата нога гази врз змија. ${ }^{44}$ Списокот на чудните суштества од визијата завршува со фигура на човек со црно тело и лице како Анзу птицата, страшна фигура.

Визијата се развива во теофанија на Нергал, кралот на Подземјето. Кога Кума го подигнал погледот, го видел снажниот Нергал на неговиот кралски престол, држејќк мрачни боздогани со двете раце. Молњи светкале во (...) неговите раце, а Анунаки, големите богови, седеле оддесно и одлево на него. ${ }^{46}$ Подземјето е ужасно страшно, раскажува Кума; моќна тишина се протегала пред принцот. Нергал го потегнал Кума за вратот, и кога Кума го погледнал, му се затресле коските, ${ }^{47}$ значи доживеал токму страв од бог, налик на ниеден друг земски страв. Мрачниот сјај на Нергал го

40 "The Underworld Vision of an Assyrian Prince", r.6.

${ }^{41}$ Op. cit., r.7.

${ }^{42}$ Op. cit., r.8.

${ }^{43}$ Op. cit., r.9.

${ }^{44}$ Op. cit., r.10.

${ }^{45}$ Во Гиліамеш, човек со глава на Анзу го влечка Енкиду во Подземјето. Сонот што го имал е дека небесата извикале, земјата им одговорила, и се појавил човек со црно лице, кое наликувало на Анзу; рацете му биле шепи на лав, а ноктите како орелски канџи (кој потоа го повлекол за косата и го совладал), - користен е текстот од Standard Babylonian Version Tablet VII, 165-171. Сандерс обрнува внимание на ес-

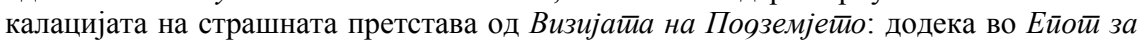
Гиліамеш описот на суштеството е со слични зборови, тој оди од „неговото лице беше многу темно“ (VII, 169), до „неговото тело беше црно како катран $(32,10)$, Sanders, "The First Tour of Hell: from Neo-Assyrian Propaganda to Early Jewish Revelation”, 159. За текстот на Гиліамеш, види А. R. George, The Babylonian Gilgamesh Epic: Introduction, Critical Edition and Cuneiform Texts. 2 vols. (Oxford-New York: Oxford University Press, 2003), 642-643.

46 "The Underworld Vision of an Assyrian Prince", r.11-12.

${ }^{47}$ Op. cit., r.13. 
совладал Кума, и тој клекнал со стравопочит пред извонредната божественост, што е вообичаена реакција пред кратофанија од овој тип. Нергал го повишил гласот, како рикачка бура од гнев кон Кума, и го подигнал скиптарот, соодветен за бог и ужасен како змија отровница, за да го покоси. ${ }^{48}$ Рикајќи, Нергал го фаќа Кума за косата (повторно може да се забележи сличност со сонот на Енкиду), имајќи намера да го убие. Сепак, неговиот советник го советува да го поштеди Кума, за тој да може покајнички да се врати во горниот свет за да го слави Нергал. Нергал ја преиначува смртната казна во пророштво и предвидува политичка нестабилност: немири, насилни чинови и бунт, ${ }^{49}$ кои ќе му го нарушуваат сонот (тој, исто така, наредува да не биде заборавен или занемарен). ${ }^{50}$ Кума забележува чудно суштество, и иако не прашува за него, Нергал го идентификува „ова“ како дух (или труп). Нергал објаснува дека тие останки се од овчар кому таткото на Нергал му дарил наполно владеење, според што се работи за опис на кралската сувереност на починатиот предок. Нергал потоа го опишува и како освојувач и високиот свештеник на Ашур, ${ }_{52}^{51}$ улога резервирана за неоасирскиот крал. $^{52}$

Потоа Нергал му кажува на принцот дека се работи за неговиот предок. ${ }^{53}$ Нергал потем завршува со клетва, нарушувајќ́ ја рамката на раскажувањето со тоа што се обраќа на кој и да е оној кој слуша (со второ лице множина), против кој и да е оној кој би ги занемарил зборовите на Сенахериб. Кума се буди и има напад на престрашено каење. Приказната отстапува од него, и се концентрира на лик „оној писар“ (веројатно споменат на оштететниот дел од текстот), кој е, всушност, двојник на принцот - како него, и тој е грешник кој го зазема местото на неговиот татко. Набљудувајќи ги дејствата на принцот, и тој си го зема сериозно предупредувањето на Нергал: оди и ја повторува приказната пред луѓето во палатата, велејќи „нека ова биде мое искупување“.

Во текстот на Визијайа е значајно наведувањето на писарски список на описи на божествените нешта. Форматот на GTT е познат од бројни контексти, но во оваа инстанција се работи за различен вид на врамување, не објективно, во гласот на сезнаечки говорник во трето лице од научните текстови, туку во прво лице, на мошне личен начин, на некој кој го видел (и почувствувал) она за

\footnotetext{
${ }^{48}$ Op. cit., r.14-r. 15.

${ }^{49}$ Op. cit., r.20-r.21.

${ }^{50}$ Ibid.

${ }^{51}$ Op. cit., r.21, r.24.

52 Ова е можна историска идентификација со Сенахериб. За градењето на куќата на Акиту, епитетите на кралот и други детаљи од содржината на текстот за Сенахериб, во А. Y. Ahmad, A. K. Grayson, "Sennacherib in the Akitu House", Iraq 61

53 "The Underworld Vision of an Assyrian Prince", r.26.
} (1999): 187-189. 
кое раскажува. Не се работи за копии, за гипсени модели на фигурини од подземните божества, како што се опишани во текстот од $G T T$, туку за самите богови. Кума, значи, ги искусува изворните божествени форми на кои се повикуваат фигурите и текстовите. Од теофанијата на Нергал, принцот до срж се уплашува („,г погледнав и моите коски потреперија; неговата мрачноосветлувачка блескавост ме совлада“). ${ }^{54}$ Поради она што го научува од Нергал, и од целото застрашувачко искуство, принцот е променет. Искуството може да се смета за иницијациско. Принцот поминува низ најопасниот чекор во мистичкото спуштање, заканата за уништување, но бива спасен и предупреден, и добива повеќе знаење отколку што имал пред визијата, во неговата претходна (неиницирана) cocтојба. $^{55}$

Нергал го објаснува идентитетот на суштествата кои сонувачот ги гледа во Подземјето, што значи дека митските мотиви биваат објаснувани низ егзегеза. Ова одговара со научничкиот список на божества и демони со кои започнува Визијайа, како и идентификацијата на раскажувачот (принцот), со писарот со кој се затвара раскажувањето. $^{56}$

Во асирските палати биле поставувани фигури, чувари на портите, апкалу или други Misch/en/wesen, кои припаѓале на армијата на Тиамат. ${ }^{57}$ Иако овие суштества имаат изглед што сега се

${ }_{55}^{54}$ Op. cit., r.19.

55 Ваквото лично искусување е типично за описите на нуминозните искуства. Така, посветениот верник или учесникот во ритуалот ги искусува нештата и настаните од митското време. Шаманот/магот лично ги искусува ликовите и местата од митот. Покрај тоа, употребата на традиционалните митски поими низ личносни искуства е типична за апокалитичкиот жанр. Една од хипотезите на Елијаде е дека екстазата како искачување постоела пред екстазата како descensus ad inferos. Прво, coништата и визиите кои се однесуваат на издигнувањата се универзално потврдени, и побројни од сонишата за симнување во Подземјето. Искачувачката екстаза е директна: директно се разбира и не бара развиена интерпретативна теорија. Интерпретацијата на екстазата на симнувањето во Подземјето подразбира и идеологија и техника: човек се симнува за да помине низ смртта (како вид на иницијација) и да постигне повторно раѓање како нов човек. За небесните патувања и симнувањата во подземјето и улогата на шаманот како психопомп, во поглавјата VI и VII, од М. Eliade, Shamanism: Archaic Techniques of Ecstasy (London: Arkana, Penguin Books, 1988).

56 За употребата на демонстративните честици и деиктичките објаснувања како основна карактеристика на набројувањето во овој текст и во развојот на еврејската егзегеза, кај M. Himmelfarb, Tours of Hell: An Apocalyptic Form in Jewish and Christian Literature (Philadelphia: University of Pennsylvania, 1983), 6.

57 Атач забележува дека постои поместување во уметноста во палатите, од претставите на апкалу до мешаните суштества (Mischwesen), како што се оди низ хронологијата на неоасирскиот период. Додека уметноста на Ашурнасирпал II ги претставува само апкалу, палатите на Саргонидите покажуваат силно инклинирање кон хибридите на Тиамат, особено лавот-демон угалу. Според Атач, претпочитањето на суштествата на Тиамат е резултат на силната бабилонска политика на Саргонидите, како и доаѓањето на Енума елиш во Асирија, вклопувањето на космогонија- 
смета за чудовишен, а со тоа зол, тие може да се замислат како испитувачи низ патот на иницијацијата. Некои од овие суштества припаѓале на небото исто толку колку што биле дел од Подземјето. За многу од нив се верувало дека имаат свои пандани како cosвездија на небото, и многу од нив се појавуваат на бабилонските плочки и релјефи меѓу другите небесни симболи. Она што е интересно е што описите на некои од жителите на Подземјето од Визијайа соодветствуваат со дел од претставувањето на мешаните суштества од палатите од Нинива, на пример. Злиот дух (utukku lemnu) имал глава од лав, неговите раце и нозе биле тие на Анзу. Подземните хибридни жители се вооружени - што одговара со идејата за мачна иницијација во животот отаде.

Кога Атач се осврнува на овие демонски суштества во палатите, тој расправа дека „демонската“ и напати деструктивна природа што ги карактеризира може да се разбере како начин за скривање на духовната привилегираност на асирската научничка интелектуална елита. Независно дали се антедилувијалните мудреци или членовите на војската на Тиамат, заедничкиот аспект на овие мешани суштества е нивната врска со космичката прото-историја, разбирањето на раѓањето на светот. На некој начин, како претходните господари на вистината да дошле до подоцнежните времиња маскирани како чудовишта. ${ }^{58}$ Ова е интересна конекција, имајќи ја предвид нивната позиционираност на влезовите, портите и премините, како чувари, испитувачи и претседавачи со ритуалите на премин, и како обезбедувачи на територијата, низ месопотамската и староегипетската традиција. Покрај ова, треба да се има предвид амбивалентната природа: претставите на фантастичните суштества треба да се гледаат и како апотропејски - чудовишното (и зло) потомство на Тиамат после поразот станува сила на добро, sверките стануваат добронамерни и заштитнички духови; нивното претставување како чувари низ палатите исто така има и апотропејска функција.

Како што беше споменато, редовите од Визијайа кои се однесуваат на суштествата со кои Кума се среќава во Подземјето, додека оди кон престолот на Нергал, имаат специфична структура чија содржина и синтактичка организација е изведена од форматот на

та во асирската „теологија“, и заменувањето на Мардук со асирскиот национален бог, М.-A. Ataç “'The Underworld Vision' of the Ninevite Intellectual Milieu”, Iraq 66, Nineveh. Papers of the 49th Rencontre Assyriologique Internationale, Part One (2004): 71.

${ }^{58}$ Ataç “'The Underworld Vision' of the Ninevite Intellectual Milieu”, 74.

${ }^{59}$ A. Green, "Beneficent Spirits and Malevolent Demons. The Iconography of Good and Evil in Ancient Assyria and Babylonia“, Visible Religion. Annual for Religious Iconography (Leiden: E. J. Brill, 1984), 86; J. M. Russell, „The Program of the Palace of Assurnasirpal II at Nimrud: Issues in the Research and Presentation of Assyrian Art", American Journal of Archaeology 102 (1998): 674. 
$G T T .^{60}$ Во GTT се опишува изгледот на статуетките на божествата, низ кратки реченици во кои се следи стандардизирана схема на презентација, од горе кон долу (значи, од „главата до петиците”). ${ }^{61}$ Некои од примерите би можеле да бидат следниве. Главата е опишана како глава на кисугу-риба. Лицето е тоа на човек, образот како украсен. Ушите се кучешки, а рацете на човечко суштество. Ставен му е околувратник. Носи оружје. Од неговата глава до појасот е човек, а од појасот до (...) тој е (...). Неговото име е Илаб $(\ldots)$. $^{62}$

Понатаму, опишано е дека главата носи рогови. Лицето е човечко. Текстот продолжува: тој има образи, неговите раце се човечки, со прекурамник од јагнешка кожа е покриен на градите, и опашан со појас, врзан со шамија. Неговото тело е човечко. Неговото десно стапало е изложено од (...) нагоре и стои цврсто. Неговото лево стапало и двете нозе се изложени, и со нив стапнува врз Анзу-птицата. Неговото име е Нинурта. ${ }^{63}$ За следното суштество пишува дека има рогови како вол; косата му паѓ од неговите рогови по грбот. Неговото лице е човечко; образот е украсен. Ова е суштество со крила; а предниот пар стапала му се воловски. Неговото тело е на лав, и чекори со четири пара стапала. ${ }^{64}$

Како што беше нагласено, во Визијат̄а на Пояземјейо не се опишуваат прикази на боговите во форма на статуетки, туку директно суштествата, онака како што се покажани во непосредното искуство на визијата. Ова значи дека иако недостасува елементот на докажливост, на постоечки, проверлив и потврден физички објект како референтна точка, се воведува елементот на сведочење, на означувач кој се повикува на сопственото (иако апсолутно интимно) искуство на визијата (,(jac) видов...“). Во обата начина на прикажување, и од GTT и од Визијайа на Пояземјейо, обрнато е внимание на аспектите на манифестацијата на боговите - на нивниот изглед и божествени карактеристики - преку слична описна схема.

Споменати беа некои од описите од Buзијат̄а. Опишано е како злобниот дух е прикажан со човечка глава и раце, крунисан со

${ }^{60}$ Станува збор за документот уреден од Кохер - F. Kocher, „Der babylonische Göttertypentext“, MIO 1, 1953: 57-107. GTT не треба да се помеша со англискиот формат на God Type Texts (текстови за типови на богови) на Ливингстон, A. Livingstone, Mystical and Mythological Explanatory Works of Assyrian and Babylonian Scholars (Winona Lake: Eisenbrauns, 2007), 92-112. Во овие, деловите на телото на едно божествено суштество, исто така организирани од главата до петиците, се изедначуваат, на навидум езотеричен начин, со органски и неоргански материјал, како животни, растенија, артефакти, и со други божествени суштества.

${ }^{61}$ J. Bach, "A Transtextual View on the 'Underworld Vision of an Assyrian Prince"”, S. V. Panayotov, L. VacÍn (Eds.), Mesopotamian Medicine and Magic - Studies in Honor of Markham J. Geller (Brill, Leiden-Boston: Brill, 2018), 77.

\footnotetext{
${ }^{62}$ GTT, i17'-25'.

${ }^{63}$ Op. cit., i51'-ii 10.

${ }^{64}$ Op. cit., iv23-33.
} 
дијадема, со раце (односно, посоодветно, крила) на орел, како со едната нога згазнува врз крокодил. Овој зол дух, или Алухапу, има лавовска глава, а човечки четири пара раце и нозе. ${ }^{65}$ Чуварот на злото има птичја глава, според раскажувањето на Кума, раширени крила со кои лета наваму и натаму, неговите раце и нозе се човечки. Овој подземен бродар има глава на Анзу-птица. ${ }^{66}$ Потоа, деифицираната Заклетва има козја глава, човечки раце и стапала. Неду, кој е носач на подземниот свет, има лавовска глава, а човечки раце и птичји нозе. Апсолутното Зло има две глави, од чии описи е зачуван само тој на едната од главите, лавовската.

Во споредбата меѓу двата типа на набројувања се забележува дека текстуалната схема што се појавува во Визијайа е како скратена и делумно извртена верзија од примерите од $G T T{ }^{67}$ Додека детаљите од GTT се потемелни и нудат побогати описи, во Bизијай се опишуваат главата, рацете и стапалата, и можеби додатни една или две карактеристики на суштествата видени во личното искуство на принцот. Во GTT името на суштеството доаѓa после описот, а во Визијайа името доаѓ прво, како претставување на суштеството, а потоа неговиот опис. ${ }^{68}$

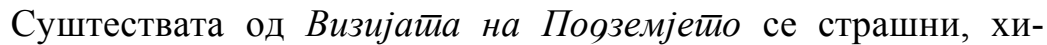
бридни, чудовишни, но не се демонски. Тие се дел од злокобната атмосфера што се очекува од Подземјето, но нивните функции и дејства не се на зулумџии, талкачи, носачи на болести и на несреќи, карактеристични за демоните. Тие не се зли по себе, туку имаат улоги на чувари, дејствители или служители на Нергал, што значи дека иако предизвикуваат непријатност и ужас кај посетителот на Подземјето, не се закануваат на вообичаената, профана сфера на надземскиот секојдневен живот, како што прават демоните.

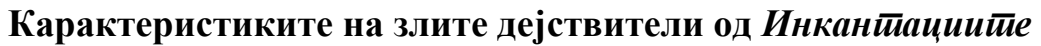 иройив зли оемони (Уوуі-хул инканйациитее)}

За разлика од темелните списоци на божества карактеристични за месопотамската теологија, не постојат собрани и организирани материјали во форма на списоци на демони. Ова веројатно се должи на нивниот онтолошки статус и нивните функции. Во пописот на небото и земјата демоните не се вбројуваат. Списоци на демони и споменувањата на класи или групи на демони постојат, но

\footnotetext{
65 "The Underworld Vision of an Assyrian Prince", r.4.

${ }^{66}$ Op. cit., r.5.

${ }^{67}$ Bach, "A Transtextual View on the 'Underworld Vision of an Assyrian Prince"”, 79 .

${ }^{68}$ Низ теоријата на транстекстуалноста на Женет, овој дел од Визијайа може да се чита како хипертекст на GTT, или, попрецизно, како негова транспозиција (иста макросодржина, но различна структура), G. Genette, Palimpsests (Lincoln-London: University of Nebraska Press,1997), 98.
} 

не се во космолошки, туку најчесто во магиско-медицински кон-
тексти.

Како примордијалните Чудовишта, и демоните немаат култови. Но, за разлика од Чудовиштата, кои стапиле во служба на боговите, демоните се космички одметници, невклопени талкачи по рабовите од цивилизацијата од која не може да бидат дел. Демоните талкаат од храм до храм, но затоа што нема брашно ритуално растурено за нив, никаква божествена жртвена понуда, нивното однесување станува агресивно. Немаат храмови во кои би имало собирања, како што има за боговите, та затоа демоните не може да слушнат никакви молитви или молби. Низ егзорцистичките ритуали на демоните им се вели да се задоволат со понудата на храна и пијалок која се дава на духовите, и да си заминат.

Утуку (претходно удуг) се нејасна класа на демони, за кои понекогаш се сметало дека се добри, а понекогаш дека се зли. Во егзорцистичките текстови се случува да се повика добар удуг (утуку) против зол удуг (утуку). ${ }^{70}$ Гудеа, владетелот на Лагаш, бара од божицата да му прати добар удуг за да го штити, и лама(су), заштитнички бог, да го води (на еден од два цилиндри на Гудеа). Во текст од Стариот бабилонски период се бара: „нека злиот удуг и гала стојат настрана. Нека добриот удуг и добриот галу ${ }^{71}$ бидат присутни“. 72

${ }^{69}$ Обемниот асирски речник издаден од Ориенталниот институт при Универзитетот во Чикаго, Chicago Assyrian Dictionary $(C A D)$, ги содржи имињата на дваесет и пет лични и заштитни духови, сто и деветнаесет духови кои се зли (вклучувајќи ги овде и подземните службеници и амбивалентните удуг, односно утуку), меѓу кои дваесетина се демонизирани болести, тринаесет се видови на духови, помалку демонизирани животни, ветришта (на бурата), места, временски периоди и апстрактни концепти. Покрај ова, постои и група од персонифицирани демонски дејства или карактеристики (како “бестрашниот“, „беззакониот“, „набљудувачот“, „грабливецот“ и други), The Assyrian Dictionary of the Oriental Institute of the University of Chicago, Chicago: Oriental Institute of the University of Chicago vol. 1-26, 1956-2011. <oi.uchicago.edu/research/publications/assyrian-dictionary-oriental-institute-university-chicago-cad. Ова е прелиминарно пребројување и бездруго би било подложно на промени и дополнувања при потемелна анализа.

70 За амбивалентноста на удуг, а дури и на лама, која е генерално добронамерно суштество, односно за ретките појавувања на зла лама, како и паровите на добар удуг и (добра) лама, кај G. Konstantopoulos, "Shifting Alignments: The Dichotomy of Benevolent and Malevolent Demons in Mesopotamia", S. Bhayro, C. Rider (eds.), Demons and Illness from Antiquity to the Early-Modern Period (Leiden-Boston: Koninklijke Brill, 2017), 23, 26.

${ }^{71}$ Галу (gallû) или гала се великите демони од месопотамското Подземје. Галу демоните ги повлекуваат несреќните жртви во Подземјето. За галу се верува дека биле дел од седумте „ѓаволи“ (или потомството на пеколот) од бабилонската теологија, кои можеле да бидат (дискретно) одоброволени преку жртвени дарувања (од типот на јагне). Позната била приказната во која Инана била следена од галу демони откако била испратена надвор од Подземјето од Галатура и Курјара. Од Симнувањетио на Инана во Поэземјешио се знае дека таквите демони не знаат за храна, за пијалок, не јадат жртвени дарови од брашно, ниту примаат либации. За нив се веру- 
Амбивалентноста на удуг потекнува и од разбирањето на терминот. Изворно, името не покажувало дали демонот за кој станува збор е добро или зло суштество. ${ }^{73}$ Со терминот „удуг“/,утуку“ може да се реферира на целата демонска категорија, а не на специфичен вид на демон, и не секаде мора да стои определбата „хул“ (hul), односно „лемну“ (lemnu). Нема јасно идентификувани визуелни претстави на утуку, но постојат описи, според кои утуку демоните имаат класични месопотамски демонски карактеристики (сенка без никаква светлина што ја опкружува, отровност, заглушувачка гласност). Удуг може да биде индивидуален, или цел список на демони што го спопаднале пациентот. Така, во инкантација се споменуваат зол намтару кој ја сардисал главата на болниот, зол утуку (utukku lemnu), кој го сардисал грлото, алу кој ги зграпчил градите, зол етему кој му ги зграпчил рамењата, зол галу (gallû) кој му ја зграпчил раката, рабису, пак, стапалата: го покриле овој човек како мрежа. ${ }^{74}$

Удуг е зол предизвикувач на физичка разболеност, еден од бројните (видови) демони, од кои ниеден не е издвоен како помоќен, или на друг начин различен од другите. Константопулос нотира дека во овој список на демонски фигури се гледа пристап типичен за месопотамските инкантации: со текстот мора да се покријат сите можни демони кои можеби му влијаат на пациентот, на тој начин покривајќи ги сите можни причини за болеста. ${ }^{75}$ Еден (или повеќе) од овие зли предизвикувачи ќе биде точниот, што значи дека нема да биде сторен дијагностички пропуст. Концептот за mimma lemnu, демонот „што било зло“, бил вклучуван на крајот на списо-

ва дека не уживаат во задоволствата на сопружничка прегратка, ниту имаат „слатки дечиња за бакнување“. Тие го грабнуваат синот од скутот на татка си; предизвикуваат невестата да побегне од куќата на свекорот, "Inana's descent to the netherworld", J. Black, Jeremy, G. Cunningham, E. Flückiger-Hawker, E. Robson, J. Taylor, G. Zólyomi (Eds.), Electronic Text Corpus of Sumerian Literature, Oxford University, etcsl.orinst. ox.ac.uk/section $1 / \operatorname{tr} 141 . h t m$. Овие формулации за уништување на семејните интерперсонални односи се мошне често застапени во Инканйащиитеие йройив уяуі хул, како што ќе може да се забележи од следниот дел од текстот.

Повикувањето на добар галу не е вообичаен концепт, затоа што не се работи за амбивалентни суштества, туку очигледно зли и штетни. Терминот „галу“ може да се употребува и за човечки соперници, не само за демони. Слично на ова, изворното значење на „сатана“ е исто така каков било соперник, противник, „камен на сопнување“.

72 Текст 244, 17-20, G. Cunningham, Deliver Me from Evil: Mesopotamian Incantations, 2500-1500 BC, Studia Pohl: Series Maior, 17 (Roma: Editrice Pontificio Instituto Biblico, 2007), 128.

${ }^{73}$ J. Black, A. Green, Gods, Demons and Symbols of Ancient Mesopotamia - An Illustrated Dictionary (London: The British Museum Press, 1992), 179. $160-170$.

${ }^{74}$ E. E. Knudsen, "Two Nimrud Incantations of the Utukku Type", Iraq 27 (1965):

${ }^{75}$ Konstantopoulos, "Shifting Alignments: The Dichotomy of Benevolent and Malevolent Demons in Mesopotamia", 26. 
ците на посебните демони во инкантациите, за да се знае дека биле „неутрализирани сите потенцијални закани“. 76

Во месопотамските магиски текстови специфично се споменува зол удуг, како и множина, за кои се вели дека се зли. Имињата

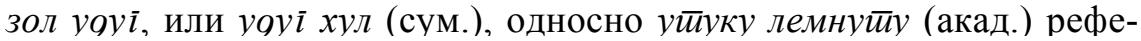
рираат на злиот аспект, но, како што беше споменато, и само „Удуг“ веќе ја има конотацијата на злото. 77 Удуг е најраспространетиот и најчесто споменуван од сите демони во Месопотамија, но нема забележани суштински карактеристики или карактер. Зборот уяуi може да се однесува на демоните како целина, односно е најблискиот термин во целата категорија на натприродни суштества што денотира генерички означувач за демони. И кога удуг дејствува индивидуално, нема забележана специфична природа. Се знае дека често служи како вектор за болеста, физичка или ментална, и во оваа смисла во инкантациите се појавува како дејствител на злото. Но, покрај ова дејствува и како помагач на егзорцистот, што значи дека иако во текстот на инкантациите генерално е зол, во ритуалот има помошна (добронамерна) функција.

Со оглед на способностите на удуг да предизвикуваат и добро и зло, Канинхем тврди дека посоодветен термин би бил „дајмон“" наместо „демон“. ${ }^{78}$ Класата на утуку лемнуту меѓу другите ги содржи следниве суштества. Алу е демонизиран атмосферски феномен, веројатно изворно идентичен со алу во смисла на Бикот на небото. Потоа, се вбројува асаку, како персонифицирано прекршувањето на табуто и неговите консеквенции, нередот, болеста, бунтовниот дух - ова е и општ збор за демонот на болеста (,безредие“), и името на митолошкиот непријател на Нинурта (,„Безредие“), а со тоа и општ термин за бунтовен или одметнат бог. Понатаму, концептот за рабису (прикривачот, кој се наоѓа во влезовите на куќите, празните премини и напуштените простори, подготвен да нападне) како понизок службеник, кој, преку наредбите на космичките авторитети се застапува за причините на праведноста, и извршувањето на одлуките; се работи за вид на штетен прикривач, вампирски дух, но и службеник, бранител, чувар. Покрај овие постојат и шеду - дух, аспект на душата, демон, што е машкиот контрапункт на Ламасу. ${ }^{79}$ Главната карактеристика на утуку е што навјасува со болест и страдање.

${ }^{76}$ J. Scurlock, Magico-Medical Means of Treating Ghost-Induced Illnesses in Ancient Mesopotamia (Leiden: Brill, 2005), 503.

${ }^{77}$ Konstantopoulos, op. cit., 27.

${ }^{78}$ Cunningham, Deliver Me from Evil: Mesopotamian Incantations, 2500-1500 BC, 39.

79 Терминолошки гледано, ситуацијата е комплицирана. Така, злобниот удуг, или удуг хул (,демон“, или попрецизно удуг-демон) во билингвалните текстови и лексичките списоци на акадски јазик е преведуван како уйуку, но за „дух“ се употребува специфичниот термин іияим (односно етемем). Добронамерниот удуг-дух 
Релативно добро зачуваната билингвална магиска серија од доцниот трет милениум, Инканйациитее ирротиив зли яемони, е најран и најсистематичен извор за месопотамските демони. Во корпусот се содржат егзорцизми и прочистувачки ритуали против голем

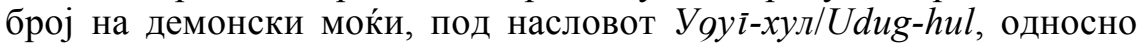

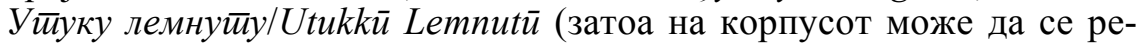
ферира како на почетокот на овој текст, Инканйации йройив уяуі

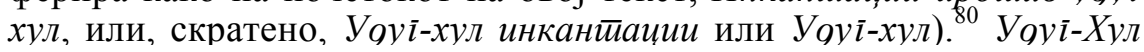
се смета за канон за егзорцизмот на зли удуг демони. Традицијата на инкантациите од текстот ја опфаќа целата месопотамска историја. Инкантациите биле едни од најраните текстови на сумерски јазик во третиот милениум пр. н. е., како и едни од последните месопотамски текстови од доцната антика, напишани со клинесто

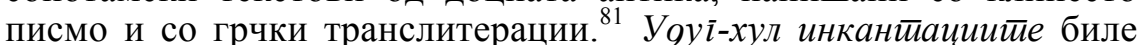
изворно еднојазични (на сумерски јазик), а потоа двојазични, на сумерски и на акадски јазик. Покрај тоа, низ времето биле дополнувани и проширувани со додатоци само на акадски јазик, без претходни сумерски варијанти. Во Уоуї-хул инканйациийе се подвлекува улогата на злобниот удуг како причина за болеста и се нагласува важноста на егзорцистот во лечењето. Магиско-медицинската идеја е да се набрка демонот за да може да се излечи болеста. Низ инкантациите има чести референци на месопотамската митологија, како приказната за симнувањето на Инана во Подземјето.

Утуку демоните потекнуваат од раниот, ембрионски космос, кој во месопотамската космогонија се смета за состојба на „сѐ уште не“, која затоа и бива така опишувана, како на пример во првиот ред од Енума елии (кога горе небесата сѐ уште не биле именувани). Предците на утуку најчесто се сметале како производ на Небото и Земјата, кои направиле произведувачки пар (принципи), пред нивното разделување од страна на Енлил. Во други концепции демоните се сметале за роднини на Енки и Нинки, на други приморди-

(преведуван како „шеду“) дејствува со женскиот контрапункт, како што беше споменато, Лама(су), како аспект на душата, како натприроден заштитник на луѓето и зградите (удуг во оваа смисла е шеду или рабису). За јазичките разлики прецизно кај Wiggermann, “The Mesopotamian Pandemonium - A Provisional Census”, 310.

80 Удуг-демоните не се појавуваат во инкантациите од Урук III од Нипур, каде се пронајдени најголем дел од старобабилонските сумерски инкантации од серијата У9уї-хул-а-кам. Оваа серија е претходник на, а не идентична со, подоцнежните канонски серии од Нинива или Ашур, М. J. Geller, Forerunners to Udug-hul, Sumerian Exorcistic Incantations (Freiburg: Franz Steiner, 1985), 5. Гелер реферира на Уوуї-хул-

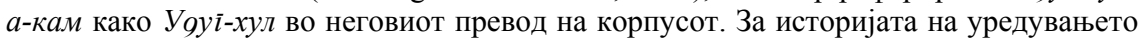
на корпусот, кај M. J. Geller, Healing magic and evil demons: canonical Udug-Hul incantations (Boston: De Gruyter, 2015), 3-4. Инкантациите од Нипур исто така немаат стандардни списоци на демони, кои се толку добро познати од подоцнежните Уïy-хул-а-кам и другите билингвални инкантации, каде удуг-демонот се појавува како заглавје на списокот, секогаш во иста фиксна секвенца, M. Geller, “The Faceless Udug-demon", Studi e Materiali de Storia delle Religioni 77/2 (2011): 333-334.

${ }^{81}$ M. J. Geller, Healing magic and evil demons: canonical Udug-Hul incantations, 3. 
јални парови, на Светата планина (планина во смисла на издигнување), родното место на Енлил, или на Апсу, примордијалното место под краевите на земјата. ${ }^{82}$ Понекогаш се сметаат за деца на алу, примордијалните божества-работници, чија побуна довела до антропогонијата. Демоните немаат бог, меѓутоа, немаат жив божествен родител пред кого би одговарале, и кој за нив би бил одговорен. Демоните не се богови, но сепак нивните гласови се силни, а нивниот сјај е воздигнат. Интересно е што и покрај овој божествен сјај, демоните имаат многу темна сенка, како воопшто да нема светлина во нивните тела. Демоните учествувале во примордијалниот космос како нетелесени, атопични суштества без карактеристики, општо земено негативно дефинирани со наполна туѓост, без форма. Недостатокот на претставување во визуелните медиуми оди во контекст на непостоењето на култ кон демоните (култ не би се развил без статуи во храмовите и претстава за објектот на верувањето).

Удуг (утуку) демоните се отаде чудовишност во нивниот изглед. Тие не се ни машки ни женски; немаат партнери и деца; и, иако може да се сметаат за инкарнирано зло, тие не се телесни. Се работи за нетелесни суштества без уста, без екстремитети, без лице, без сетила како вид или слух. Тие биле скриени и не можеле да се видат ни на дневна светлина. Имињата на демоните не постојат на Небото и на Земјата (што кореспондира со нивното невбројување во космичкиот попис). Како удуг (утуку) изгледаат не е познато од богатата магиска книжевност, и може да се претпостави дека иако магиско-медицинските работници и нивните пациенти не знаеле каков е демонот, знаеле што предизвикува, и имале начини на справување со неговото штетно влијание. За удуг постојат само неколку описи, и нема идентификувани визуелни претстави. Фактот што и нема којзнае што визуелно да се претстави го објаснува овој недостиг. ${ }^{83}$

${ }^{82}$ Еден од главните заклучоци (или, поскоро, исходишна точка, или хипотеза, а потоа заклучок) на општиот преглед на (класата на) демоните на Вердераме е дека најголем дел од карактеристиките на демоните укажуваат на нивниот примордијален и посреднички статус, што резултира со непотполна, или ограничена, или недефинирана суштина. Во оваа врска со примордијалната фаза (демоните како создадени од страна изворните космолошки парови, наспроти сукцесивното настанување на боговите), Вердераме го гледа разлогот за отсутните или недефинирани карактеристики, како чудовишноста и лиминалноста. Ставовите се провлекуваат низ целиот текст, а заклучоците се резимирани на L. Verderame, "'Their Divinity is Different, Their Nature is Distinct!' Nature, Origin, and Features of Demons in Akkadian Literature", Archiv für Religionsgeschichte 14 (2013): 126.

${ }^{83}$ Со тоа што постојат некои месопотамски печати на кои е претставена фигура со скиптар покрај добронамерната Лама(су), може да се претпостави дека, ако таа фигура е удуг, тие сепак биле и визуелно претставувани. Слики од Лама(су) и удуг биле често употребувани за да ги штитат влезовите, T. Ornan, The Triumph of the Symbol: Pictorial Representation of Deities in Mesopotamia and the Biblical Image Ban (Academic Press Fribourg and Vandenhoek \& Ruprecht Gottingen, 2005), 19, 43. 
Иако следењето на семиотичките податоци од различните термини за $y q y \bar{l}$ и други демони и нивната употреба може да помогне, сепак не е доволно да се добие јасна дефиниција за тоа што месопотамскиот демон претставува. ${ }^{84}$ Секако дека удуг е демон тежок за дефинирање, особено без да се познаваат значењата на другите термини што биле употребувани за што било демонско од древните

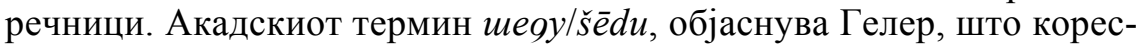
пондира на сумерскиот алая, воопшто не е поинформативен - како и удуг, и ала(д)-демонот може да биде лош (hul/lemmu) или добронамерен ( $\mathrm{sa}_{6} /$ damqu), што повторно ја означува амбивалентноста на демонот. Односно, демонот е изворно вредносно неутрален, а станува амбивалентен и може да наштетува или да заштитува, во зависност од неговата ориентација. Сепак, Гелер жали што, со измислување на нови вредности за знаците што се употребуваат да ги означуваат овие термини, научниците всушност ги замаглиле нивните значења. ${ }^{85}$

Терминот $y \bar{u} y \kappa y$, како позајмица од сумерскиот $y 9 y \bar{\imath}$, не кажува речиси ништо за карактерот на демонот, и не додава ништо повеќе отколку она (речиси ништо) што се знае за удуг од сумерските контексти, смета Гелер. Во овие инкантации добро се гледа генеричката употреба. Во нив удуг-демонот (злиот бог, кој е зол удемон), е опишан како жител на степата, планината, морето или гробницата. ${ }^{86}$ Според ова, уgyi или уйуку е генерички термин за geмон. Почесто, сепак, кога удуг-демонот се појавува сам во билин-

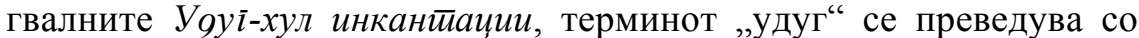
акадските "шеду“ (šédu) или „рабису“ (rābișu). Така, пишува, „талкачу демону на патишата и крстопатите, кога заминуваш сам и се враќаш сам (нека Нинурта те одбие)“; 87 „убиствениот демон на бурите е незауздан удуг“. ${ }^{88}$ Во овие примери удуг е зол и штетен, но постојат случаи на удуг самотник, во кои е претставен во подобра

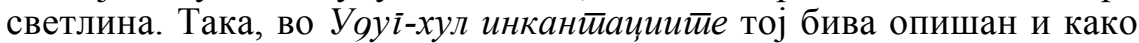
персонификација на божествен амблем, како еру/erû-дрвениот скиптар, заштитникот на Ану. ${ }^{89}$

84 За компаративниот терминолошки пристап на Гелер, кај M. J. Geller, “The Faceless Udug", 334-335.

${ }^{85}$ Op. cit., 335. За јазичките форми на $u d u g / u t u k k u$, преку концептот за злото, кај L. Verderame, "Il concetto di male nelle tradizioni dell'antica Mesopotamia", G. Mura (Ed.), Bene e male nelle religioni (Roma: Aracne, 2014), 45-56.

${ }^{86}$ Geller, "The Faceless Udug", 336.

${ }^{87}$ V, 146, Geller, Healing magic and evil demons: canonical Udug-Hul incantations. Сите наводи од Инканйацииие Уgуі-хул во понатамошниот текст се од верзијата на корпусот на Гелер, освен ако не е инаку посочено, во форматот [UH, број на таблица, редови].

${ }^{88} \mathrm{UH}, 13-15,85$.

${ }^{89}$ Op. cit., 15,$74 ; 249$. Гелер објаснува дека значењето на уوуі во овие два примера е преведено со акадското paбисy/rābișu, за кое погрешно се мисли дека е изведено од глаголот rabāṣu, „легнува“海аголот има и второ значење, „да се крие“, „да 
Во други инстанции, удуг е определуван како $m е g y / s ̌ e d u$, термин генерички колку и уйуку. Удуг демонот, како шеду, може да се појавува и во добра и во зла форма, како и во случајот со рабису. Од друга страна, демонот е асоциран со Ламашту/lamaštu, која е ceкогаш зла и нема добронамерност во нејзината природа. Во инкантациите се споменуваат плунка (односно отров, или отровна плунка) на $\check{s} \bar{e} d u$ и на Ламашту. ${ }^{90}$

Гелер се осврнува и на логограмот а.pa (a.rá), употребен за шеду, односно и за утуку (поради блискоста по значење на термините). ${ }^{91}$ Ова е релевантно затоа што едноставното генеричко значење на двата акадски термина, шеgу и уйуку, во смисла на „демони“, се однесуваат на демонското дејствување како носител и проширувач на болест, и тоа така што дејствуваат во служба на божество. Тие дејствуваат како заменици, или извршители на божеството, во смисла на идентификување на болеста со „раката на бог“. Идејата за интервенирачката рака на бог е типична за бројни религии, но тука се однесува токму на определувањето и назначувањето на болеста како „рака“ на некој партикуларен бог. Постојат чести примери за овоі концепт во Дијаіносииччкиой ирирачник (Ca$\kappa u \kappa y / S a k i k k \bar{u} / S A . G I G)$, стандардниот учебник за етиологија и прогноза на болестите. ${ }^{92}$ Сепак, определбата на „рака“ на некаков бог или демон или дух често реферира на вообичаените симптоми на болеста, така што асоцијацијата со божеството или демонот кој ја предизвикува болеста е веројатно второстепена. ${ }^{93}$

демне чекајќи“, Geller, “The Faceless Udug”, 336. Всушност, потсетува Гелер, сумерскиот еквивалент за именката rābișu е maškim (машким), што се однесува на судски извршител или чиновник. Акадскиот еквивалент, rābișu, исто така бил судски службеник од понизок ранк. Ова е интересно од социјално-правен аспект. Имено, заклучокот што може да се изведе од сумерските и акадските определби на демоните е дека овие термини, во демонски контексти, реферираат на корумпирани службеници, од чие зло влијание нема избавување. Ова објаснува и како демонската позиција и авторитетот на удуг може да бидат перципирани или како изживување на бирократ кој прави опструкции и зулуми, или како посветеност на натприроден бирократ кој помага.

${ }^{90} \mathrm{UH}, 15,191$.

${ }^{91}$ Geller, "The Faceless Udug", 339.

92 Детално за процесот на дијагнозата на болеста кај N. P. Heeßel, "Diagnosis, divination and disease: Towards an understanding of the rationale behind the Babylonian Diagnostic Handbook", H. F. J., Horstmanshoff, M. Stol, C. Van Tilburg (Eds.), Magic and rationality in Ancient Near Eastern and Graeco-Roman medicine (Leiden: Brill, 2004): 97-116.

${ }^{93}$ Во прегледот на болестите предизвикани од страна на духови на Скурлок се содржат само неколу референци на удуг-демони, затоа што во сите други уяуі е едноставно претворен во gyx (гедим), Scurlock, Magico-Medical Means of Treating Ghost-Induced Illnesses in Ancient Mesopotamia, passim. Во Еӣой за Гилїамеи, за духот на Енкиду се вели дека е утуку/ú-tuk-ku, XII, 83. 
Разликата која Гелер ја идентификува меѓу „демон“ и „дух“ е што првиот е професионалец, а вториот е „,аматер“.94 Ова е совршено јасна дистинкција. Демоните биле создавани и праќани од страна на Енлил токму за да казнуваат или да предизвикуваат штета. ${ }^{95}$ Духовите, пак, се души кои биле на некаков начин оштетени: незакопани мртви, луѓе на чие име никој не се сеќава, или кои претрпеле предавство, или починале невини без да создадат потомство. ${ }^{96}$

Утуку-демонот не се појавува во дијагнозите и прогнозите, иако Прирачникоти, како што е очекувано, е дел од магискиот корпус. Во Прирачникой не се појавува никаква болест „рака на удуг“. Наместо тоа, се појавува (речиси единствено) духот или гедим / етиму, и тоа како „рака на духот“ како дијагностичка категорија. Удуг или утуку демонот не е застапен во магиските состави од доцниот прв милениум (на пример, низ Еіалкура инйанйациииее или хемерологиите). Гелер, чија статија се однесува на потрагата по лицето на безличниот удуг, смета дека резултатите се разочарувачки, затоа што едноставно нема доволно материјал за утуку, шеду или рабису да бидат визуализирани.

Сепак, додека не може да изненади што барањето на ликот на удуг не вродува со плод, не е дека безличниот демон е сосема без карактеристики. Се знае дека е амбивалентен, дека со научничките јазички интервенции амбивалентноста се замаглила, дека има свои пандани, и дека има одреден физикус. Вердераме неколкукратно забележува дека „физичките“ карактеристики на демоните се недистинктни и недефинирани. Во претставите и описите на демоните со чудовишен лик, обликот е човечки, а телото составено од бројни делови од други суштества, што прави ваквата хибридност да биде јасна и расчленлива. ${ }^{97}$ Во оваа „сума на делови“, ниеден не доминира, односно, поентата на хибридноста е што суштествата кои биваат анализирани не може да бидат сместени во специфична класа или група на животни. Сепак, кога станува збор за хибридни демони, ниеден од деловите што ја составуваат целината не се однесува на некаков специфичен демон. Затоа, треба да се има на ум дека иако описите на различните суштества може да се разликуваат, една иста карактеристика може да биде споделувана од разни демони. ${ }^{98}$

Постои билингвална (сумерско-акадска) инкантација во која богот Асалухи (Асарлухи, или Асарулуду) му го опишува злобниот удуг на татка си Енки (односно Мардук му опишува на Еа). Изгле-

\footnotetext{
${ }^{94}$ Geller, "The Faceless Udug", 340.

${ }^{95}$ Како божји извршители (види $U H, 3,30$ ), или биле произведувани од страна

${ }^{96} U H, 4,130$ '-149'.

${ }^{97}$ Verderame, "'Their Divinity is Different, Their Nature is Distinct!' Nature, Origin, and Features of Demons in Akkadian Literature", 123.

${ }^{98}$ Ibid.
} на Ану $(5,2)$. 
дот на удуг е злокобен, а неговата става надвиснувачка. Иако не се работи за бог, објаснува Асарулуду, неговата бучава е огромна, а неговиот cjaj (melam) извонреден. Демонот е темен, со катран црна сенка, и никаква светлина во телото. Тој секогаш се крие, засолнувајќи се, и никогаш не стои гордо. Понатаму е опишано дека од неговите канџи капе жолчка, та остава отров каде и да помине; неговиот појас не е попуштен, неговите раце ја опфаќаат (ја горат) жртвата. Демонот ја исполнува жртвата на својот гнев со солзи, и низ сите земји неговиот повик за битка не може да биде зауздан (или никаде не се воздржува од предизикување на тажачка). ${ }^{99}$ Злобниот утуку рикнал во широката степа и стадото овци било уништено, се раскажува. Бројот на сите живи суштества бил намален; пасиштето и изворите биле уништени. Во плодните ледини, пасиштата и поилата биле претворени во чад. Кога демонот се приближува на изворот и бунарот во градината, овошките паѓаат од гранките, и тој ги гази плодовите во градината и ја покрива со плевел. ${ }^{100}$

Константопулос смета дека од ваквите описи се сфаќа дека пристапот кон демонот е апофатички - се опишува што тоі не е. Демонот е безимен и бесформен, дури и во неговите рани појавувања. ${ }^{101}$ Формата на демонот не е важна во овој извадок, смета Константопулос, и наместо неа се истакнати неговите ужаснувачки способности. Вниманието е врз неговата сенка, недостатокот од светлина, неговиот отров, заглушувачката моќ на неговиот глас, карактеристики кои се вообичаени за демоните и чудовиштата низ Месопотамија. Овој скуден опис е додатно замаглен од фактот дека не е униформно повторуван низ разните извори, што значи дека описите на удуг се подложни на промени во други текстови каде овие демони се појавуваат. Во овој текст, неговата природа е јасно класифицирана со употреба на „хул“, „зол“. Секако, во оваа конкретна инстанција, придавката не е нужна за да ја означи злобната природа на демонот, која е очигледна и без неа. Во старобабилон-

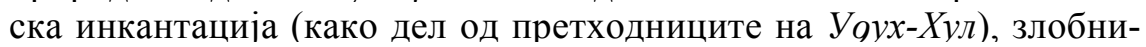
от удуг демон е идентификуван на негативен начин како оноі кој, од почетокот, не бил нарекуван по име, оној кој никогаш не се појавил со некаква форма. ${ }^{102}$

${ }^{99} U H, 12,13-20$.

${ }^{100}$ Op. cit., 12, 1-12.

101 Konstantopoulos, "Shifting Alignments: The Dichotomy of Benevolent and Malevolent Demons in Mesopotamia”, 25.

${ }^{102} \mathrm{~V}, 452-453$, користена е збирката на претходниците на Уяуї-хул од Гелер, М. J. Geller, Forerunners to Udug-hul: Sumerian Exorcistic Incantations (Stuttgart: Franz Steiner Verlag Wiesbaden GMBH, 1985). Удуг демонот е опишан и како дух кој се појавува во пустината, VI, 512. Во друга инкантација за удуг демон, која датира пред Уوуі-хул збирката, наведено е дека удуг демоните одат наоколу и им носат треска на луѓето. Тие не знаат како да си легнат в кревет, не знаат како да спијат. Ниту јадат вкусна храна, ниту пијат слатка вода. Тие ја отстрануваат жената од скутот на мажот, го подигнуваат синот од коленото на татка си, го земаат синот на чо- 
Кога студот и морниците сѐ ослабуваат, злите утуку-демони се раѓаат од семето на Ану, пишува во инкантациите. Така, Намтар (судбината), саканиот син на Енлил, е роден од Ерешкигал. Во просторот над демоните р'желе, објаснува текстот, додека во просторот под тие носеле алишта за тажачка, затоа што се производ на Подземјето. Над - тие рикаат, но под - тие цвркотат; тие се отровна плуканица на боговите. ${ }^{103}$ Во оваа инкантација се објаснува, на мошне општ и поетски начин, дека демоните се големи бури отпуштени од небесата, тие се бувот кој кричи во градот, тие се потомството на земјата преку семето на Ану. ${ }^{104}$ Демоните кружат околу високите и широки покриви, како бранови, и постојано минуваат од куќа во куќа. Тие се суштества кои ниедна врата не може да ги задржи, и ниедна брава не може да ги одврати. Демоните секогаш се провнуваат низ вратата како змија, или низ шарките на вратата навлегуваат како ветрот. ${ }^{105}$ Во следниот дел, описот на демоните реферира на уништувачкото влијание што демоните го имаат врз односите меѓу ближните луѓе. ${ }^{106}$

Демонските Седуммина се опишани како облаци надвиснати над деновите, и како зли ветришта. Тие се бури, кои се гледаат како ветер кој навестува и носи нешто лошо, тие се зли бури со лош ветер во средината. ${ }^{107}$ Седуммината демони се еквивалентни на синови и наследници, носители на Судбината (Намтар), и носачите на престолот на Ерешкигал. ${ }^{108}$ Седуммината се поплава, што секогаш клокоти низ земјата, се раскажува; тие се Седумте бога на широките неба; тие се Седумте бога на широкото Подземје. Тие се седум пљачкосувачки богови, седум зли богови, седум зли Ламашту, односно Лабасу, демони на болеста, седум на Небото и седум на Подземјето. ${ }^{109}$ Во оваа инкантација потем свечено се набркуваат злобните суштества, и, како и повеќето, и оваа инкантација завршува со резимето дека е инктантација против удуг хул. ${ }^{110}$

века од неговата свадбена куќа. Тие лазат како змии, и душкаат на подножјето на мидовите како мунгоси. Заедно со убиствени пси, сѐ набљудуваат. Во оваа инкантација се повикуваат злобниот удуг, злобниот дух и други демони да се соберат и да се набркаат од небото и од земјата. Злиот удуг е деструктивен, злиот дух и галу-демонот не спијат, се определува во текстот. Тие се зли, талкаат низ градот и ги уништуваат воловите во нивните штали, ги колат овците во трлото, го одземаат детето од скутот на доилката. Тие го убиваат таткото заедно со детето и ја прободуваат мајката со нејзините малечки како риба во морето, ор. cit., VI, 597-633.

${ }^{103}$ UH, 5, 1-7.

${ }^{104}$ Op. cit., 5, 8-10.

${ }^{105}$ Op. cit., 5, 11-15.

${ }^{106}$ Op. cit., 5, 16-18.

${ }^{107}$ Op. cit., 5, 76-78.

${ }^{108}$ Op. cit., 5, 79-81.

${ }^{109}$ Op. cit., 5, 82-90.

${ }^{110}$ Op. cit., 5, 100. 
Демоните донесуваат болести. Ослабувајќи ги и небото и земјата, демонот, со надмени раце и надмен чекор, носи зло. Демоните шерифи, се објаснува во инкантацијата, се Седумте кои немаат срам, и кои не знаат љубезно да дејствуваат. ${ }^{111}$ Тие ја толчат земјата како брашно, и не знаат никого да поштедат, беснеејќи против луѓето, јадејќи месо, предизвикувајќи крварења, а потоа пиејќи од вените. ${ }^{112}$ Во ова време (на инкантацијата), тие се слика и прилика на боговите во куќата на Светата планина каде изобилуваат овците и житото. Во оваа инкантација се повикува да бидат свечено и сигурно набркани, за никогаш да не се вратат во ниедна sирка и проsирка, ниедна пукнатина и ќошенце. ${ }^{113}$ Интересно е што во овој текст демоните се претставени како да доаѓаат од планините, односно од „далечните планини“; од Дуку, Подземјето, и како да се слика и прилика на боговите, односно како да имаат претпоставено споделено потекло со нив. Демоните, како и боговите, потекнуваат од исто место, од создавањето на природниот ред на нештата.

Во инкантациите се вклучени и такви за демони со таканаречено „добро педигре“. Се работи за два пати по седуммина „херои“ (определба која е очигледно иронична во случајов), кои биле родени од семето на Ану. Тие се фантоми, призраци, отпечатоци или бледи траги на душите (zaqīqu), кои ниту се женат, ниту носат деца, и немаат никакво разбирање. ${ }^{114}$ Тие се коњите размножени во планините, тие се злите на Еа, тие се носачите на престолите на боговите. ${ }^{115}$ Овие демони секогаш висат по улиците, за да предизвикуваат неред. Тие се појавуваат пред Нергал, храбриот херој на Енлил. ${ }^{116}$ Епитетот за Нергал е сличен со тој употребен за Нинурта. Покрај тоа, треба да се има предвид дека Нергал предизвикува страв кај демоните, поради неговата улога на господар на Подземјето.

Седуммината од изворот на Апсу, украсени во небото (украсувањето на лицето на демонот има сличен степен на иронија како определувањето како херој), се бесполови: тие се ниту машки ниту женски, тие се призраци кои брзаат наоколу, ниту се женат/мажат ниту се размножуваат. ${ }^{117}$ Седумте бесполови ниту умеат да поштедат или да спасат некого, ниту слушаат молби и преколнувања. ${ }^{118}$ Во инкантацијата потем се повторува дека се седум, два пати по седум, и дека треба да бидат отстранети и набркани.

\footnotetext{
111 Op. cit., 5, 124-130.

112 Op. cit., 5, 131-134.

${ }_{113}$ Op. cit., 5, 135-141.

114 Op. cit., 5, 150-155.

${ }^{115}$ Op. cit., 5, 156-158.

116 Op. cit., 5, 159-160.

117 Op. cit., 5, 167-173.

118 Op. cit., 5, 174-175.

${ }^{119}$ Op. cit., 5, 180-182.
} 
Злобниот утуку демон ја вџашува земјата, тој секогаш ги освојува луѓето и другите живи суштества. Таквата универзална успешност е причината за длабокоутробниот страв и потребата од постојана подготвеност за негово набркување низ инктантациите. Како дел од група, злобниот утуку демон ја пореметува земјата, и не прифаќа преколнувања. ${ }^{120}$ Тој ги прободува младите како риба во вода, ги фрла постарите во купче жито; постојано преминува од една на друга страна на широките улици, и ги замолкнува гласовите. Утуку демонот ползи низ праговите, и ги зафаќа сите суштества на земјата. Тоі ја покосува земјата - овоі демон е поплавата што се заканува. ${ }^{121} \mathrm{He}$ іа прокоцкува истурената крв, ги покорува сите луѓе, и никогаш ни глас не му се слуша. Злобниот утуку така талка по земјата. ${ }^{122}$ Демонот му приоѓ на човека, му ја допира раката, и го брка сѐ до неговата куќа, предупредувачки се објаснува во оваа инкантација, и прави да си го запушти телото: неговите очи се отворени, но ништо не гледа, ушите му се отворени, но ништо не слуша. ${ }^{123}$

Демоните се епидемија: злобниот утуку, алу, духот и шерифот демон се појавиле од Подземјето од длабочината на далечните планини, од Светата планина. Тие не се препознаваат ни на небото ни на земјата, ни седејќи ни стојеќи не биваат препознаени. ${ }^{124}$ Тие ја напаѓаат снагата на безбожниот херој, продолжува оваа инкантација, воведувајќи магиски ритуали во неговото тело. Затоа, треба да бидат набркани, од телото на жртвата, и од нејзините облеки и постела. ${ }^{125}$

Се повикуваат да заминат демоните: демонот на судбината (Намтар), Асаку и болеста, и да си тргнат злобниот утуку и алу-демонот. ${ }^{126}$ Истерувачот повикува добриот дух секогаш да биде присутен, а Ламашту, Лабасу, демоните на жолтицата, оние кои носат болест на сквернавењето (односно болест како резултат на нечистотија) и болест која не се подобрува, да си заминат. Се протеруваат и магиските ритуали и злите ритуали, главоболката, забоболката, интерно-клиничките состојби, горушицата и болката во градите; како и треската, грчевите, слабоста, инфекцијата; како и изгнаниците со зло лице, зли уста и јазик, и волшебниците, магијата,

${ }^{120}$ Op. cit., 6, 8-14.

${ }^{121}$ Op. cit., 6, 15-23.

${ }^{122}$ Op. cit., 6, 24-27.

${ }^{123}$ Op. cit., 7, 34-38.

124 Op. cit., 7, 69-72. Тие не биваат препознаени затоа што им недостасуваат фиксни физички карактеристики, но токму оваа недефинирливост ги прави поопасни, затоа што заканата од нив, иако подлежечка, сепак во конкретните случаи доаѓа ненадејно - човек нема како да се заштити од она што не го (пре)познава.

${ }^{125}$ Op. cit., 7, 78-80.

${ }^{126}$ Op. cit., 12, 220'-221'. 
сите зли магиски практики. Покрај тоа, се изгонуваат и сончаницата, отоците, сезонската главоболка, и влошувачката болест. ${ }^{127}$

Злите Седум, еден по еден, се опфатени на следниов начин. Тие се демони на бурата кои се мешаат во сешто, зли богови, непростувачки духови, кои биле родени во основата на небото. ${ }^{128}$ Тие се дејствители на штета и додатоци на злото, малициозно подготвени да убиваат секој ден. Меѓу Седумте, првиот од нив е гневниот Јужен ветер, а вториот е грабливец со отворена уста, кому никој не се осмелува да му се приближи. ${ }^{129}$ Третиот е гневен пантер; четвртиот е страшна змија; петтиот е лав кој рика, и кого никој не успева да го одврати; шестиот е бран кој се издига и ги потопува и богот и владетелот; седмиот дејствува како гласник на Ану. ${ }^{130}$ Во еден град по друг, тие го донесуваат самракот. Тие се песочни бури кои гневно талкаат по небото, тие се натежнати облаци што предизвикуваат мрак на небото. Тие се удар на ветер што се засилува, и предизвикува темнина во инаку ведриот ден. Тие се бура која поплавува, и постојано светкаат како молњи на хоризонтот. ${ }^{131} \mathrm{Ce}$ думмината се зли богови кои се искачуваат како поплава и ја облеваат земјата, оние кои се издгинуваат од земјата како бура. ${ }^{132}$

Описите на и соочувањата со разновидните зли дејствители од Инканйациийе йройив злийе яемони конзистентно ги покажуваат моќите, односно дејствата на суштествата и последиците на нивното злосторничко дејствување. Дел од постојано надвиснувачката опасност од демонската закана е во тоа што, иако се знае за нејзиниот опфат и штетност, нападите од демоните не може да се предвидат, затоа што нема суштинско познавање на тоа какви се или кои се тие. Демоните не се (пре)познаваат по лик, или по природа, иако имаат генерално лош и злосторнички карактер. За нив се знае дека носат болести, несреќи, елементарни непогоди, социјален немир, интерперсонални компликации и општа мизерија; а преку множествата на елаборирани описи се знаат нивните злокобни и застрашувачки појавувања. Против разните зли суштества мора егзорцистичко-исцелителски да се интервенира, за тие да бидат изгонети и држени на соодветна дистанција. Од Инканйациийе се дознава како егзорцистот им пристапува во магиско-медицински контекст на заштита и избавување на пациентите, односно страдалниците, со што се добива и слика за нивните функции во светот, за различните начини на кои тие предизвикуваат штети и несреќи.

\footnotetext{
${ }^{127}$ Op. cit., 12, 222'-230'.

${ }^{128}$ Op. cit., 16, 1-3.

${ }^{129}$ Op. cit., 16, 4-6.

${ }^{130}$ Op. cit., 16, 7-12.

${ }^{131}$ Op. cit., 16, 13-20.

132 Op. cit., 16, 60-63.
} 
Целта на овој текст е да даде прелиминарна слика на хибридните суштества од месопотамската митолошко-религиозна традиција, и на месопотамските концепции за инкарнираното зло преку верувањето во злите демони. Така, основните терминолошки и концептуални определби на разновидните зли демони од Инканйаиии$\bar{u} e$ не навлегуваат во компаративна анализа на партикуларните суштества, ниту во интердисциплинарно истражување на формата, содржината и значењето на инкантациите. Во текстот е само понуден избор на соодветни формулации од магиско-медицинско-книжевната месопотамска култура на борба со демонското, опседнувачкото, злото. Воведот во оваа, инаку запоставувана тема на овие простори, може да послужи како поттик за потенцијална подлабока анализа, како на партикуларните специфики на месопотамското религиозно-морално милје, така и на општата сфера на верување во злото на древните цивилизации.

\section{БИБЛИОГРАФИЈА}

Ahmad, A. Y., Grayson, A. K. "Sennacherib in the Akitu House". Iraq 61 (1999), 187189.

Ataç M.-A. "'The Underworld Vision' of the Ninevite Intellectual Milieu”. Iraq 66, Nineveh. Papers of the 49th Rencontre Assyriologique Internationale, Part One (2004), 67-76.

Bach, J. "A Transtextual View on the 'Underworld Vision of an Assyrian Prince'”, in S. V. Panayotov, L. VacÍn, Eds. Mesopotamian Medicine and Magic - Studies in Honor of Markham J. Geller. Leiden-Boston, Brill, 2018, 69-92.

Black, J. Green, A. Gods, Demons and Symbols of Ancient Mesopotamia - An Illustrated Dictionary. London, The British Museum Press, 1992.

Borger, R. "The Incantation Series Bīt Mēseri and Enoch's Ascension to Heaven", in R. S. Hess, T. D. Tsumura, Eds. "I studied inscriptions from before the flood", Ancient Near Eastern, literary, and linguistic approaches to Genesis 1-11. Winona Lake, Eisebrauns, 1994, 224-233.

Borger, R. Die Inschriften Asarhaddons, Königs von Assyrien, Graz, BAfO 9, 1956.

Collins, J. J. Seers, Sibyls and Sages in Hellenistic-Roman Judaism. Leiden, Brill, 1997.

Cory, I. P. The Ancient Fragments; containing what remain of the writings of Sanchoniatho, Berossus, Abydenus, Megasthenes, and Manetho. London, William Pickering, 1828.

Cunningham, G. Deliver Me from Evil: Mesopotamian Incantations, 2500-1500 BC, Studia Pohl: Series Maior, 17. Roma, Editrice Pontificio Instituto Biblico, 2007.

Eliade, M. Shamanism: Archaic Techniques of Ecstasy. London, Arkana, Penguin Books, 1988.

Foster, B. Before the Muses. Columbia, MD, CDL Press, 2005. 
Geller, M. “The Faceless Udug-demon”. Studi e Materiali de Storia delle Religioni 77/2 (2011), 333-341.

Geller, M. J. Forerunners to Udug-hul: Sumerian Exorcistic Incantations. Stuttgart, Franz Steiner Verlag Wiesbaden GMBH, 1985.

Geller, M. J. Healing magic and evil demons: canonical Udug-Hul incantations. Boston, De Gruyter, 2015.

Genette, G. Palimpsests. Lincoln-London, University of Nebraska Press,1997.

George, A. R. "The Dogs of Ninkilim: Magic against Field Pests in Mesopotamia". CRRAI 41, BBVO 18 (1999), 291-299.

George, A. R. The Babylonian Gilgamesh Epic: Introduction, Critical Edition and Cuneiform Texts. 2 vols. Oxford-New York, Oxford University Press, 2003.

Green, A. "Beneficent Spirits and Malevolent Demons. The Iconography of Good and Evil in Ancient Assyria and Babylonia“. Visible Religion. Annual for Religious Iconography. Leiden, E. J. Brill, 1984, 80-105.

Heeßel, N. P. "Diagnosis, divination and disease: Towards an understanding of the rationale behind the Babylonian Diagnostic Handbook", in H. F. J., Horstmanshoff, M. Stol, C. Van Tilburg, Eds. Magic and rationality in Ancient Near Eastern and Graeco-Roman medicine. Leiden, Brill, 2004, 97-116.

Himmelfarb, M. Tours of Hell: An Apocalyptic Form in Jewish and Christian Literature. Philadelphia, University of Pennsylvania, 1983.

Horowitz, W. Mesopotamian Cosmic Geography. Winona Lake (IN), Eisen, 1998.

"Inana's descent to the netherworld", J. Black, Jeremy, G. Cunningham, E. FlückigerHawker, E. Robson, J. Taylor, G. Zólyomi, Eds. Electronic Text Corpus of Sumerian Literature, Oxford University, etcsl.orinst.ox.ac.uk/section1/tr141.htm.

Johnston, S. I. Restless Dead - Encounters between the Living and the Dead in Ancient Greece. Berkeley-Los Angeles-London, University of California Press, 1999.

Katz, D. The Image of the Netherworld in Sumerian Sources. Bethseda, MD, CDL Press, 2003.

Knudsen, E. E. “Two Nimrud Incantations of the Utukku Type”. Iraq 27 (1965),160-170.

Kocher, F. "Der babylonische Göttertypentext". MIO 1 (1953), 57-107.

Konstantopoulos, G. "Shifting Alignments: The Dichotomy of Benevolent and Malevolent Demons in Mesopotamia", in S. Bhayro, C. Rider, Eds. Demons and Illness from Antiquity to the Early-Modern Period. Leiden-Boston, Koninklijke Brill, 2017, 19-38.

Kvanvig, H. S. “An Akkadian vision as background for Dan 7?". Studia Theologica Nordic Journal of Theology 35:1 (1981), 85-89.

Kvanvig, H. Primeval History: Babylonian, Biblical, and Enochic: An Intertextual Reading. Leiden, Brill, 2011.

Lenzi, A. "The Uruk List of Kings and Sagen and Late Mesopotamian Scholarship". JANER 8.2 (2008), 137-169.

Livingstone, A. Mystical and Mythological Explanatory Works of Assyrian and Babylonian Scholars. Winona Lake, Eisenbrauns, 2007.

Mayer Burstein, S. The Babyloniaca of Berossus, Sources from the Ancient Near East 1.5. Malibu, Undena Publications, 1978.

Meier, G. "Keilschrifttexte nach Kopien von T. G. Pinches. Aus dem Nachlass veröffentlicht und bearbeitet. 10. Ritual für das Reisen über Land”. AfO 12 (1937-1939), 141-144.

Ornan, T. The Triumph of the Symbol: Pictorial Representation of Deities in Mesopotamia and the Biblical Image Ban. Fribourg, Academic Press Fribourg and Vandenhoek \& Ruprecht Gottingen, 2005.

Russell, J. M. "The Program of the Palace of Assurnasirpal II at Nimrud: Issues in the Research and Presentation of Assyrian Art". American Journal of Archaeology 102 (1998), 655-675. 
Sanders, Seth L. "The First Tour of Hell: From Neo-Assyrian Propaganda to Early Jewish Revelation". Journal of Ancient Near Eastern Religions 9 (2009), 151-169.

Scurlock, J. Magico-Medical Means of Treating Ghost-Induced Illnesses in Ancient Mesopotamia. Leiden, Brill, 2005.

Smith, J. Z. "Towards Interpreting Demonic Powers in Hellenistic and Roman Antiquity". $A N R W$ II, 16. 1(1978), 425-439.

The Assyrian Dictionary, part 2. M. Civil, I. J. Gelb, B. Landsberger, A. L. Oppenheim, E. Reiner, Eds. Chicago, Oriental Institute of the University of Chicago, 1968.

The Assyrian Dictionary of the Oriental Institute of the University of Chicago, vols. 1-26. Chicago, Oriental Institute of the University of Chicago, 1956-2011. <oi.uchicago.edu/research/publications/assyrian-dictionary-oriental-institute-university-chicago-cad $>$.

"The Underworld Vision of an Assyrian Prince", A. Livingstone, Ed. Court Poetry and Literary Miscellanea. Helsinki, Helsinki University Press, 1989, 68-76.

Verderame, L. "'Their Divinity is Different, Their Nature is Distinct!' Nature, Origin, and Features of Demons in Akkadian Literature". Archiv für Religionsgeschichte 14 (2013), 117-127.

Wiggermann, F. A. M. Mesopotamian Protective Spirits: The Ritual Texts. Groningen, Styx \& PP Publications, 1992.

Wiggermann, F. A. M. "The Four Winds and the Origins of Pazuzu", in J. Hazebos, A. Zgoll, C. Wilcke, Eds. Das geistige Erfassen der Welt im Alten Orient Beiträge zu Sprache, Religion, Kultur und Gesellschaft, Wiesbaden, Harrassowitz Verlag, 2007, 125-165.

Wiggermann, F. A. M. "The Mesopotamian Pandemonium - A Provisional Census". SMSR 77 (2/2011), 298-322.

Winter, I. "The Eyes Have It: Votive Statuary, Gilgamesh's Axe, and Cathected Viewing in the Ancient Near East", in R. S. Nelson. Ed. Visuality Before and Beyond the Renaissance. Cambridge, Cambridge University Press, 2000, 22-44.

\title{
MARIJA TODOROVSKA
}

Faculty of Philosophy, Skopje

marija.todorovska@fzf.ukim.edu.mk

\section{HYBRID CREATURES AND EVIL DEMONS: AN INTRODUCTION TO THE MESOPOTAMIAN BELIEFS IN EVIL "INCARNATE"}

\author{
(SUMMARY)
}

The goal of this text is to offer a preliminary terminological and conceptual overview of the basic elements of the Mesopotamian beliefs in hybrid creatures and in the various representatives of evil "incarnate", such as the demons identified, described, and expelled through exorcisms featured in the Udug-hul (or Utukku lemnutu) Incantations. The Mesopotamian religious approaches to non-human creatures have been a topic somewhat neglected in the Macedonian intellectual milieu, which is the reason why this paper merely introduces some initial concepts from chosen literary and medico-magical sources, in order to set the stage for a more detailed and profound research, 
and does not delve into a comparative analysis of the creatures, or an interdisciplinary approach to the forms, contents, and meanings of the available sources featuring the hybrid creatures, monsters, and demons.

The main groups (and types) of creatures overviewed in the paper are the so-called "Monsters" from the accounts of the Mesopotamian cosmogony; the miscellaneous hybrids from the Underworld Vision of an Assyrian Prince; and the complex demonic forces identified as threats to be expelled by strict exorcistic healing rituals from the Udug-hul Incantations.

The text first places the concepts of hybridity and monstrosity within the understanding of liminality. The mixed creatures (Misch/en/wesen) or the creatures-in-between (Zwischenwesen) have hybrid physical forms and usually mediate between the higher and lower ontological spheres. The Monsters from the cosmogony are shown as pivotal for the events of the "not yet" of the primordial cosmos. The monsters and the demons are described as inhabitants of the liminal spaces, or the peripheries of the ordered world. Some attention is paid to the group of the Four Winds, ambivalent supernatural hybrids, who, like the Monsters, can serve in protective roles, but can also bring forth troubles (although, unlike demons, are not the cause of contagions). The Seven Sages of the Mesopotamian mythology are shown as supporters of the primordial Monsters and the Winds in their attempts to avert suffering and diseases (often caused by, or rather brought by, the demons).

The sets of hybrids and demons are not overlapping: while in the later sources most demons and underworld creatures are described as hybrid, not all hybrids are demons, and the hybridity of the demons is not a crucial point in their wickedness and harmfulness. The part of the paper which focuses on the hybrid creatures from the Underworld Vision recounts the main elements of the story of the protagonist's (the Assyrian prince Kumma) descent into the Underworld in a vision, a journey that can be considered as revelatory and initiatory. The accent is on the unmediated, intimate experience of the events in the vision (lists such as the Göttertypentext/GTT describe artefacts, while Kumma's vision is an experience of participation, not just observation, featuring the theophany of Nergal), and the fact that the protagonist is a human, not a divine creature from the mythical past. The list of the creatures inhabiting the Underworld as gloomy servants of Nergal, is mentioned as following the descriptive scheme of the GTT (head to toe, including the objects held or handled, and stood on). The depiction of these frightening mixed creatures is summarized, thus offering some possible conceptual solutions for the Macedonian reading public.

The udug (or utukku) demons are overviewed in the paper as difficult to define. These demons, a myriad of nefarious evil-doers, proliferators of disease, and creators of misfortune, remain poorly defined, as they have no known essential characteristics or accessible natures (except for the obvious wickedness). The majority of the instances involving evil demons from the Incantations against them involve elaborate descriptions of the demonic functions - the ways they spread destruction and misery (individual and universal) and the consequences of their harmful actions. The physical characteristics of the demons are often described in an apophatic manner, as being beyond monstrosity in their appearance, non-gendered, atopical, incorporeal, faceless, devoid of senses, extremities, light, and sound (although in some instances they shriek deafeningly). The demons are restless wanderers, having no cults, no designated places in the cosmic environment.

The class of udug (or utukku) is unclear and vaguely (or sporadically) ambivalent. There are no clear visual representations of udug, but there are 
typical Mesopotamian descriptions of their demonic properties (like being utterly devoid of light, venomous, disruptively loud, etc.). The text shows the difficulties in defining the udug demons, also due to the fact that they can either be individual creatures, or entire gangs of demons possessing the patient (of the exorcistic ritual). Some terminological options are outlined, with references for further lexical research, as the angle of the paper is not philological.

In the incantations chosen for this paper, and recounted mainly towards the end of the text, the udug are generally shown as lacking a (known) specific nature, or essential attributes. The udug demons are known through their actions - they serve as vectors for disease (physical and mental), and as a maleficent cause of environmental, agricultural, social, and interpersonal troubles and suffering, and therefore must be ritually banished in exorcistic healing rituals. The multi-layered portrayals of their wicked abilities from the Udug-hul Incantations accentuate the constantly looming danger of the demonic threats, only further exacerbated by the fact that while it is known what the demons can do, it is not clear who they truly are (besides being harmful), and the belief that they come without a warning, and can strike at any time. 
